\title{
Bank Corporate Governance and Future Earnings Predictability
}

\author{
Sabur Mollah ${ }^{1}$ (D) $\cdot$ Omar Al Farooque ${ }^{2} \cdot$ Asma Mobarek $^{3} \cdot$ Philip Molyneux $^{4}$ \\ Received: 30 December 2016 / Revised: 9 November 2018 / Accepted: 29 January 2019 / \\ Published online: 26 February 2019 \\ (C) The Author(s) 2019
}

\begin{abstract}
This study examines the impact of corporate governance on earnings predictability (future cash flows) for banks operating in 71 countries over the period 2007 to 2016. We find that board structure and CEO power have a significant influence on future cash flows. In contrast, risk governance variables have no significant influence. These findings vary between developed and emerging countries, common and civil law countries, and different sized banks. Board structure is more effective in predicting future cash flows in civil law and developed countries than in common law and emerging economies.
\end{abstract}

Keywords Earnings predictability $\cdot$ Corporate governance $\cdot$ Bank $\cdot$ GAAP/IFRS

JEL Classification $\mathrm{G} 21 \cdot \mathrm{G} 32 \cdot \mathrm{G} 38$

\section{Introduction}

An extensive literature examines how corporate governance and reporting quality impacts earnings but these issues have little been addressed in the banking area. The extant non-bank literature on earnings quality or earnings management typically link these to possible influences including: institutional ownership (Velury and Jenkins 2006); book-tax conformity (Atwood et al. 2010); gender diversity (Ye et al. 2010); board characteristics (Mashayekhi and Bazaz 2010); internal control regulation (Altamuro and Beatty 2010); employee expenses (Schiemann and Guenther 2013); the characteristics of chief financial officers (Dichev et al. 2013); and various country-level institutional factors (Kanagaretnam et al. 2014). Our study extends this literature by using bank governance indicators such as board structure, CEO

Sabur Mollah

s.mollah@sheffield.ac.uk

1 Sheffield University Management School, University of Sheffield, Sheffield, UK

2 UNE Business School, University of New England, Armidale, Australia

3 Cardiff Business School, Cardiff University, Cardiff, UK

4 College of Business Administration, University of Sharjah, Sharjah, UAE 
power, and risk governance, to examine the determinants of earnings predictability of future cash flow $\left(\mathrm{CFO}_{\mathrm{t}+1}\right)$, a forward-looking earnings quality indicator, of banks from 71 countries across the globe.

The collapse of the world's leading financial giants such as Lehman Brothers and Citibank during the global financial crisis of 2008-2009 triggered policy maker interest in bank governance issues (BIS 2014; OECD 2010). Effective corporate governance in banking is important given the large information asymmetries, opaqueness and complexities characterising the sector (Levine 2004). Bank managers face challenging issues arising from dealing with diverse types of risk (Nichols et al. 2009) and this can force widespread discretionary managerial choices (Bamber et al. 2010) that may, or may not, be in shareholders' interests. Effective governance should encourage banks to take acceptable levels of risk while minimising the likelihood of bankruptcy (Erkens et al. 2012; Beltratti and Stulz 2012). Such governance structures can help increase financial reporting transparency (Chen and Jaggi, 2000) and therefore enhance earnings quality as this enables more accurate prediction of future cash flows. This makes it easier for banks to plan in terms of capital allocation, investment and meeting regulatory requirements. It also helps boost investor confidence and managerial reputation.

Moody's survey ${ }^{1}$ of 62 international banks illustrates that global banks have been strengthening governance practices and addressing attitudes to risk appetite. The survey shows that banks are restraining managerial discretion relating to delaying the reporting of loan-losses from non-performing loans and provisioning. This again suggests that effective governance structures matter for banks' earnings quality. Moreover, the legal and institutional environment can also serve as a monitoring mechanism to reduce agency conflicts and ease governance problems between investors and managers (Bathala and Rao 1995; Mak and Li 2001).

Earnings quality has received considerable policy attention since the global financial crisis when banking systems were substantially re-shaped (Dechow et al. 2010; Prior et al. 2014) and new regulations on bank financial reporting quality have subsequently been introduced (Altamuro and Beatty 2010; Kanagaretnam et al. 2014). The concept of quality earnings is fundamental in accounting and financial economics, yet there are broad disagreements about how it should be defined and measured (Dichev et al. 2013). ${ }^{2}$ Regarding measurement issues, the debate focuses on whether 'accounting-based' (accruals quality, earnings management, persistence, predictability, and smoothness) or 'market-based' (relevance and timeliness) indicators are the most appropriate to gauge earnings quality. Conceptually, however, quality is deemed 'high' if current earnings can better predict future cash flows, as well as the long-run profits, of the firm (Velury and Jenkins 2006; Dichev et al. 2013; Schiemann and Guenther 2013). Quality is regarded as 'low' if managers have an incentive to manipulate earnings figures opportunistically (Healy and Wahlen 1999; Dechow and Skinner 2000; Rosenfield 2000; Dechow et al. 2010). Both agency and signalling theory deal with such manipulation issues in the context of asymmetric information problems that are reduced through improved corporate governance and financial reporting standards.

\footnotetext{
${ }^{1}$ See http://ww2.cfo.com/governance/2015/08/risk-governance-improving-big-banks/

${ }^{2}$ High-quality earnings have been defined/measured in the literature as those that are: persistent and hence the best predictor of future long-run sustainable earnings; smooth; predict future earnings; backed by past, present, or future cash flows; have, and / or have small changes in total accruals that are not linked to fundamentals (Dechow and Dichev 2002; Schipper and Vincent 2003; Dechow and Schrand 2004; Francis et al. 2004; Kothari et al. 2005; Melumad and Nissim 2009).
} 
The quality of accounting information derives from International Financial Reporting System (IFRS) standards and US Generally Accepted Accounting Principles (GAAP). Under the IFRS/GAAP framework, the current earnings of firms are reflected in their future operating cash flows $\left(\mathrm{CFO}_{\mathrm{t}+1}\right){ }^{3}$ Earnings predictability is an important measure as it deals with how well past earnings can explain current and future earnings and this can lead to more accurate valuations as it enables investors to better anticipate expected future cash flows (Velury and Jenkins 2006; Schiemann and Guenther 2013). Earnings predictability is a forward-looking measure of earnings quality as opposed to earnings management which is backward-looking. It provides a better understanding of expected future cash flows $\left(\mathrm{CFO}_{\mathrm{t}+1}\right)$ derived from the company cash flow statement rather than the comprehensive income statement, which more likely determines future bank investment and lending activities (Hasan et al. 2012). Managerial discretion and manipulation are more pronounced in reporting earnings in the income statement (namely, through accrual-based accounting), than through changes in operational cash flows (using, cash-basis accounting measures). Despite the importance of earnings quality and predictability to banks, however, the extant literature is somewhat limited.

Prior banking literature documents that managers use discretion in financial reporting for several reasons, to: signal private information; manage risk; meet or beat earnings benchmarks; and to avoid adverse compensation and career consequences (Kanagaretnam et al. 2004, 2010; Bushman and Williams 2012; Dechow et al. 2012; Dichev et al. 2013). Cornett et al. (2009) show that U.S banks use their discretion to smooth earnings during periods of low profitability by delaying the reporting of loan-losses and increasing the realization of securities gains. Under higher investor protection, banks may prefer forward-looking loan-loss provisioning and have a greater incentive to recognise larger provisions in order to smooth income - this has a negative bearing on future earnings predictability. While the purpose of loan-loss provisions is to adjust banks' loan-loss reserves to reflect expected future losses, bank managers may also have incentives to use them to manage earnings and regulatory capital (Ahmed et al. 1999; Prior et al. 2014). As noted by Pérez et al. (2008) the accrual of loan-loss provisions is left to bank managers' discretion. However, the literature is somewhat inconclusive as to the link between loan-loss provisioning and earnings. Collins et al. (1995) find evidence of a positive link whereas Beatty et al. (1995) find no evidence of earnings smoothing.

Reforms to IFRS and U.S GAAP have not only made the standards more similar but have also aimed at improving earnings quality (see Dichev et al. 2013). Barth et al. (2008) contend that IFRS limits the opportunity of management to engage in opportunistic behaviour by restricting accounting options available to them. Leventis et al. (2011) also find that IFRS has been beneficial to users of financial reports as it has reduced opportunistic behaviour in earnings management. Although, the occurrence of earnings manipulation is hard to unravel (Dechow et al. 2010), a lack of correspondence between 'earnings' and 'cash flows' and deviations from industry and other peer experience can provide helpful indications of earnings management practice (Dichev et al. 2013). Altamuro and Beatty (2010) argue that internal control requirements can increase the validity of loan-loss provisioning and this aids (among other things) earnings persistence and cash flow predictability. Kanagaretnam et al. (2014) find an association between measures of earnings quality (as measured by earnings persistence and cash flow predictability) and strong country-wide legal, extra-legal and political institutions.

\footnotetext{
${ }^{3}$ Dechow and Schrand (2004) contend that high-quality current earnings is a better predictor of future cash flows and that earnings with high predictive value are associated with a stronger relation between earnings and future cash flows (Velury and Jenkins 2006).
} 
They also find that institutional factors can constrain opportunistic earnings management behaviour in banks.

The global financial crisis also raised questions about the link between corporate governance and bank earnings. For non-bank firms it has been shown that weak corporate governance structures result in poorer earnings quality (du Plessis et al. 2005; Hashim and Devi 2007; Jo and Kim 2007). Developments in corporate governance mechanisms and the introduction of IFRS/GAAP have generally improved earnings quality and reduced opportunistic behaviour (via tougher monitoring systems) (Dechow et al. 1996; Klein 2002; Xie et al. 2003; Cormier and Martinez 2006; Jo and Kim 2007; Shen and Chih 2007; Kent et al. 2010 and Prencipe and Bar-Yosef 2011). Some of these monitoring mechanisms relate to strengthening inside corporate governance through legal and disclosure related legislation (macrolevel), and through improved systems and procedures at the firm-level (micro-level) (Agrawal and Chadha 2005; Hope and Thomas 2008; Altamuro and Beatty 2010, Holm and Schøler 2010; Kanagaretnam et al. 2014). In conjunction with compliance with IFRS/GAAP standards, various other governance mechanisms such as, board characteristics, CEO power and risk governance can also (if working properly) positively influence earnings quality by restraining managerial manipulations detrimental to firm value.

This paper examines the impact of corporate governance on the predictability of future cash flows $\left(\mathrm{CFO}_{\mathrm{t}+1}\right)$, (a forward-looking measure of earnings quality), using a sample of 306 large, medium and small commercial banks and bank holding companies (BHCs) chartered in 71 countries over the period 2007-2016. Our approach is (to some extent) in-line with Cornett et al. (2009), Altamuro and Beatty (2010) and Kanagaretnam et al. (2014), where we use the cash flow predictability measure as the main indicator of earnings quality. Cornett et al. (2009) study the relationship between earnings management and governance indicators for large U.S bank holding companies (BHCs). They use data from the 100 largest publicly traded BHCs from 1994 to 2002 and find that reported earnings, board independence, and capital are negatively related to earnings management. Altamuro and Beatty (2010) study the effect of internal control regulation on financial reporting. Based on U.S and international banks over 1986-1992 and 1995-2001 they document improvements in earnings' persistence and predictability of cash flows and find evidence of reduced earnings management activity in the form of benchmark-beating. They also find a decrease in accounting conservatism due to various internal control regulations. Overall, their main conclusion is that improvements in internal control monitoring and reporting lead to an enhanced quality of financial reporting in the banking industry. Kanagaretnam et al. (2014) study the impact of international institutional factors on earnings quality. Using a large sample of non-US banks from 35 countries over 1993-2006 they report that cash-flow predictability is higher in countries with stronger legal, extra-legal and political institutional structures. Both studies use loan-loss provisions to capture earnings management in the banking sector. While our study extends Cornett et al. (2009), Altamuro and Beatty (2010) and Kanagaretnam et al. (2014), we investigate earnings predictability of future cash flows (namely, $\mathrm{CFO}_{\mathrm{t}+1}$ ) and corporate governance relationships rather than focusing on loan-loss provisions-based earnings management and institutional factors directly. Moreover, unlike the aforementioned studies, we rely on future cash flows from the company cash flow statement rather than future earnings or comprehensive performance from the income statement, primarily because managerial discretion is greater in measuring earnings compared to operational cash flows. Given the phenomenon of managerial discretion and accrual-based earnings, we also argue that current earnings are likely to be a better predictor of future cash flows compared to current cash flows, consistent with Greenberg 
et al. (1986) and Dechow et al. (1998). As for our key empirical findings, we find that board structure and CEO power have a significant influence on the earnings predictability of banks. The results vary for emerging and developed countries, and common and civil law countries as well as different bank sizes.

Our study contributes to existing research in several ways. First, to the best of our knowledge, this is the first study to use an extensive international sample of banks across a large number of countries (71) countries (over 2007-2016) which enables us to investigate the link between corporate governance and earnings predictability in not only developed and emerging economies but also across economies with varying legal and other institutional features. We show a positive and significant relationship between current earnings and $\mathrm{CFO}_{\mathrm{t}+}$ ${ }_{1}$, indicating that current year's reported earnings are an important predictor of future earnings. Small boards with more independent directors also help predict future cash flow $\left(\mathrm{CFO}_{\mathrm{t}+1}\right)$ whereas CEO duality (where the CEO also acts as the Chairperson) is more likely to have a negative effect on future earnings predictability. We further report that having a risk committee member on the board is positively associated with $\mathrm{CFO}_{\mathrm{t}+1}$. These findings are consistent with both Velury and Jenkins (2006) and Atwood et al. (2010) who show that future cash flows are positively linked to current earnings.

Second, in-line with Pathan (2009), Pathan and Faff (2013) and Mollah and Zaman (2015) we argue that bank governance factors are effective in enhancing earnings quality and reducing risks. Cornett et al. (2009) suggest that corporate governance plays some role in earnings and earnings management at large U.S. banks as they find a significant negative relationship between earnings management and board independence. Our focus on the link between corporate governance indicators and $\mathrm{CFO}_{\mathrm{t}+1}$ is motivated by the conceptual framework of IFRS/GAAP, which suggests that users and investors should obtain quality information from financial reports to assess $\mathrm{CFO}_{\mathrm{t}+1}$. We find (as expected) a significant influence of board structure and CEO power on earnings predictability of our sample banks (but we do not find any strong relationship with risk governance variables). Our study, therefore, provides empirical evidence consistent with the signalling theory built on financial reporting under the IFRS/GAAP regime as well as agency theory predictions from the regulatory environment concerning board structure and CEO-power in explaining earnings predictability.

Third, banks are highly regulated, compared to non-banks, and need to not only comply with accounting standards and listing requirements on disclosure, but also on a wide range of other regulatory requirements (Basel requirements, domestic supervisory regulations and so on). Among explanations as to why banks exposed themselves to excessive risks during the run-up to the global financial crisis was that there was a failure of risk management (Ellus and Yerramilli 2013). This motivates us to investigate whether predicted earnings of banks are influenced by bank risk governance features. We find little evidence that bank risk governance features impact earnings predictability.

Finally, while existing studies mainly use samples of large banks, we focus on a broader range of bank sizes across a larger number of (71) countries. This enables us to investigate earnings predictability from a wider range of perspectives, namely: across different legal regimes (civil vs. common law countries); stages of economic development (developed vs. emerging economies); and for varying bank sizes (large to small). Kanagaretnam et al. (2014) find that banks' cash-flow predictability is higher in countries with stronger legal, extra-legal and political institutional structures. Overall, our results vary between developed and emerging countries, common and civil law countries, and large, medium and small sized banks. Board structure is more effective in predicting future cash flows in civil law and developed countries 
than in common law and emerging economies. CEO power reduces future earnings predictability in common law and emerging countries while less so in civil law economies (and to some extent increasing predictability in developed countries). Risk governance also indicates variations in influence between civil and common law countries as well as across developed and emerging economies. In general there is greater similarity in the influence of risk governance in common law and emerging countries although overall they do not appear to have a significant influence. Again, governance variables also have a differential influence on earnings predication for banks of varying size.

The remainder of the paper is structured as follows: Section 2 provides an overview of literature and hypotheses on board structure, CEO power and risk governance while Section 3 discusses the methods, data and model specifications; Section 4 focuses on the empirical results and robustness tests and finally Section 5 provides the concluding remarks.

\section{Related literature and hypotheses development}

A number of studies measure earnings quality by assessing the ability of earnings to predict future cash flows (Doyle et al., 2003; Cohen et al., 2004; Francis et al., 2004; Van der Meulen et al., 2007; Melumad and Nissim, 2009; Atwood et al. 2010, 2011). Researchers use different proxies for earnings quality such as: earnings management; accrual quality; earnings predictability; smoothness; persistence; earnings informativeness; and benchmark beating (Francis et al. 2004; Dichev et al. 2013). Another indicator of quality relates to earnings with a high predictive value, namely, a strong association with future cash flows. Lipe (1990) considers earnings predictability as the ability of earnings to explain itself. If past earnings are good estimates of current earnings, then predictability is said to be high. The quality of firms' earnings relates to the usefulness of accounting information to financial statement users. While quality of earnings is a concept having multidimensional constructs, the foundation of earnings quality derives from the 'conceptual framework' of accounting standards, namely the IFRS/ GAAP regime. IFRS/GAAP promote quality disclosure and reporting and as a consequence financial reports are designed to provide value relevant information. In the IFRS/GAAP framework, both relevance and reliability are viewed as the two principal qualitative characteristics of earnings numbers. To be relevant, among other things, earnings numbers must have predictive value. The predictive nature of accounting earnings is also manifest in valuing firm's equity which also requires investors to anticipate expected future cash flows (Velury and Jenkins 2006). Dechow (1994) contends that current earnings generally produce better predictions of future cash flows. Current earnings figures are believed to be of higher quality the more they can predict future cash flows, and the quality of current accounting information is firmly rooted in strict compliance to IFRS/GAAP based accounting standards.

Furthermore, firms with higher earnings quality are more likely to have good governance systems that signal the reliability of their financial reporting processes (Engel 2005). The direct and indirect agency costs relating to managerial incentives can be mitigated through several mechanisms. It is argued that good governance assists in aligning managers' interests with those of shareholders via reduced agency costs. Similarly, CEO power has also been found to be linked to the quality of firm financial statements (Zhang and Wiersema 2009). Agency theory predicts that powerful CEOs tend to be entrenched and operate detrimentally (to shareholders) by extracting private benefits of control, including, empire building (Jensen 1986). Good governance therefore recommends the separation of the role of CEO and 
Chairperson as well as promoting a larger number of independent board members (Shleifer and Vishny 1997). In the same vein (and since the global financial crisis) it has been suggested that risk management mechanisms be emphasised more in the governance of banks and other financial firms (Mongiardino and Plath 2010; Sabato 2010; Aebi et al. 2012). In particular, the aforementioned studies emphasize greater risk-reporting to the board (rather than the CEO), and to check the power of CEOs thus reducing possibilities for opportunistic behaviour. The following incorporates these issues in our methodology on bank earnings predictability as outlined below.

\subsection{Board structure and earnings predictability}

Agency theory suggests that board independence acts as a watchdog over a firm's operations and provides monitoring incentives for reducing agency costs. The existence of independent directors on the board therefore is expected to enhance earnings ability to predict future cash flows. Chen and Jaggi (2000) provide evidence that board independence is crucial in influencing the level of superior financial reporting. Cheng and Courtney (2006) document a significant positive association between the proportion of independent directors and the extent of reporting quality.

Again, board size is also one of the factors influencing the effectiveness of board oversight duties. There has been continued debate on the role of board size, although agency theory suggests that larger boards support more effective monitoring (Coles et al. 2008; Pathan 2009). Small boards are favoured for: being easier to co-ordinate; quicker in making decisions; less likely to have free-rider problems; and more likely to be innovative (Dimitropoulos and Asteriou 2010; Mollah and Zaman 2015; Pathan 2009). Xie et al. (2003, p. 300) point out that "A smaller board may be less encumbered with bureaucratic problems and may be more functional. Smaller boards may provide better financial reporting oversight". Vafeas (2000) and Cho and Rui (2009) find that earnings numbers of firms with small boards are more informative. However, there are opposing views about large boards and their role in monitoring. Empirical studies conclude that a greater number of board members will likely lead to more independent directors and provide more expertise, experience, knowledge and diversity and increase the board's monitoring capacity (Dalton et al. 1998; John and Senbet 1998; Dalton et al. 1999; Linck et al. 2008). Rahman and Ali (2006), however, point out that large boards can be less effective in reducing earnings manipulation.

Given the mixed evidence on board independence, size and earnings quality, we hypothesize that board structure, ${ }^{4}$ especially a strong board structure (smaller board size and greater independence) helps improve the earnings predictability of banks:

H1: Board structure has an effect on earnings predictability.

Or - Small and independent boards have a positive effect on earnings predictability.

\subsection{CEO power and earnings predictability}

The governance literature defines CEO power in a variety of ways: CEO duality; internallyhired CEO; and CEO tenure (May 1995; Hermalin and Weisbach 1998; Morck et al. 1989;

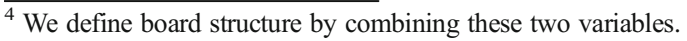


Adams et al. 2005; Pathan 2009; Fracassi and Tate 2012; Mollah and Zaman 2015). A CEO becomes more powerful when they also chair the board (CEO-duality) and such power grows with employment tenure and if the CEO is internally-hired (Pathan 2009; Fracassi and Tate 2012; Mollah and Zaman 2015). CEO power can be entrenched thereby restricting information flows to other board directors, impacting board decisions and undermining the board's independence to oversee managers. Pathan (2009) documents that CEO power is negatively related to bank risk-taking, namely, bank CEOs have incentives to take less risk to secure their jobs and human capital investment by accepting some safe value-reducing projects, and rejecting risky but value-increasing projects (May 1995; Saunders and Cornett 2006). Similarly, in the earnings informativeness literature, CEO duality seems to have a detrimental effect on the usefulness of earnings numbers (Gul and Lai 2002; Anderson et al. 2003; Firth et al. 2007). Combining two roles (chairperson and CEO) along with longer tenure exacerbates the potential for managing earnings, thus impairing the quality of reported earnings (Saleh et al. 2005; Prencipe and Bar-Yosef 2011). Similarly, other CEO characteristics, such as whether the $\mathrm{CEO}$ was an internal appointment and the length of tenure can also have a negative bearing on financial statement quality and therefore earnings predictability (Pathan 2009; Fracassi and Tate 2012). Following the aforementioned agency theory views we propose a second hypothesis:

\section{H2: CEO power has a negative effect on earnings predictability. \\ Or-CEO-duality, CEO-internal and CEO tenure have negative effects on earnings predictability.}

\subsection{Risk governance and earnings predictability}

In recent years, risk management has become an integral part of governance in the banking sector. Mongiardino and Plath (2010) outline best practice in banking risk governance and highlight the need to have at least a dedicated board-level risk committee, of which a majority of members should be independent, and also that the Chief Risk Officer (CRO) should be part of the bank's board (Aebi et al. 2012). Both Aebi et al. (2012) and Ellus and Yerramilli (2013) note that risk governance (having a CRO on the board as well as a Risk Management Committee) matters for bank risk-taking as they perform risk monitoring functions. As banks are at the center of undertaking risky business, the main purpose of the risk management function is to mitigate the risk of large losses, known as tail risk (Ellus and Yerramilli 2013). Ellus and Yerramilli (2013) suggest that a strong and independent risk management function in banks can curtail such tail risk exposures. Kashyap et al. (2008) and Stulz (2008) also contend that the presence of a strong and independent risk management team is necessary to control tail risk exposures of financial institutions.

Policy makers around the globe have emphasized the importance of appropriate risk management practices being applied in financial institutions, including the existence of a risk management committee and appointment of a CRO (Brancato et al. 2006; Sabato 2010). Therefore, risk governance mechanisms, together with clear CRO reporting lines are important components of bank corporate governance. A strong risk management function is necessary to correctly identify risks and prevent excessive risk-taking (Kashyap et al. 2008; Stulz 2008) that cannot be controlled entirely by regulatory supervision or external market discipline (Ellus and Yerramilli 2013). Similarly, the role 
of the CRO and other risk managers is also important to evaluate the viability of bank's loans and other investments. Risk managers or CROs can limit a bank's propensity for excessive risk-taking.

Again, female directors are "more risk-averse to fraud and opportunistic earnings management" (Man and Wong 2013, p. 391) than their male counterparts. In suggesting that women are generally more conservative and less inclined to take excessive risks in banks (Palvia et al. 2014), Sunden and Surette (1998) also reveal that female directors are more riskaverse in making decisions. Srinidhi et al. (2011) demonstrate that the participation of woman directors on boards increases the quality of reported earnings. But, Sun et al. (2010) find no relationship between female directors and earnings management and Berger et al. (2014) indicate that a higher proportion of female board members increases bank portfolio risks. Despite diverse results on the link between risk governance and earnings predictability, we propose the following hypothesis:

H3: Risk governance has a positive effect on earnings predictability

Or the presence of a-Risk committee, chief risk officer and female directors have a positive effect on earnings predictability.

\section{Data and method}

\subsection{Data}

We primarily focus on a sample of (all) listed commercial banks and BHCs with accounting data available in Bankscope and market data available in Datastream over 2007-2016. We retain only institutions with an independent ownership structure defined by the database (nonindependent banks such as subsidiaries can be influenced by the parent). The remaining banks should have at least four years of accounting, market and governance data. The selection criterion leads to a sample of 306 banks from 71 countries. We present the sample distribution in terms of country and year in Table 1. Panel A shows the country distribution, which indicates a high proportion of banks in Japan and the U.S. For example, we have 61 banks from Japan and 27 from the US in the sample.

\subsection{Methodology}

First we apply OLS estimation to our baseline models and then two-step system GMM for robustness checks. System GMM can effectively address endogeneity/causality concerns between the variables used (Arellano and Bond 1991; Blundell and Bond 1998; Arellano and Honoré 2001).

\subsection{Model specification}

We use the following model to test our hypotheses in-line with Cornett et al. (2009), Altamuro and Beatty (2010), Kanagaretnam et al. (2014) and others in the literature:

$$
\mathrm{CFO}_{\mathrm{i},(\mathrm{t}+1)}=\alpha+\beta_{1} \operatorname{ROIAA}_{i, t}+\beta_{2} C G_{i, t}+\beta_{3} \operatorname{ROIAA}_{i, t}{ }^{*} C G_{i, t}+\beta_{4} X_{i, t}+\beta_{5} M E_{i t}+\varepsilon_{i, \mathrm{t}}(1)
$$



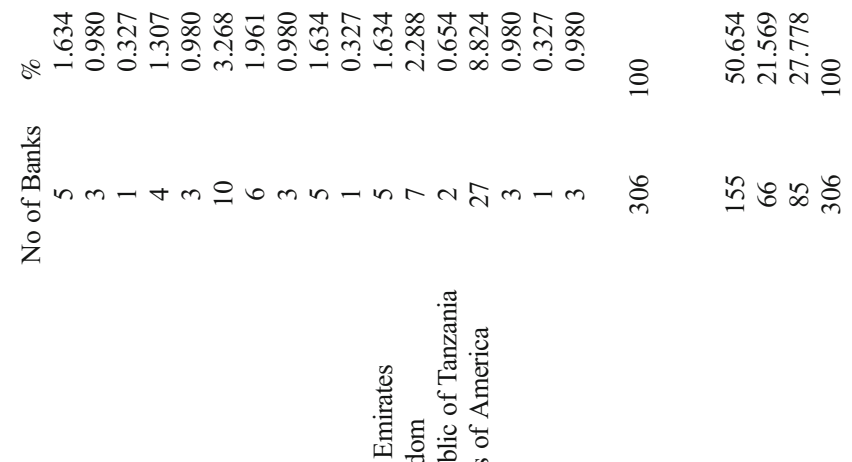

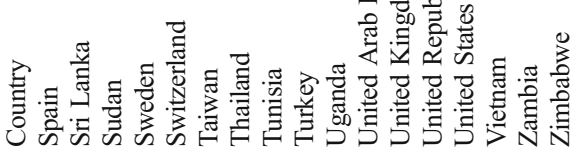

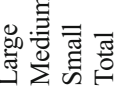

ฉ

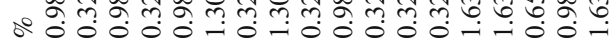

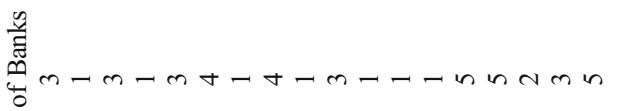

空

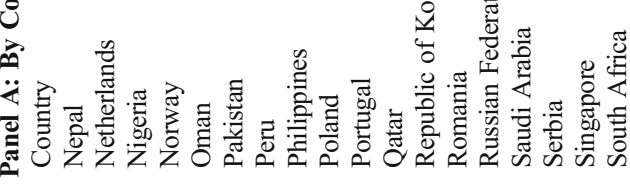

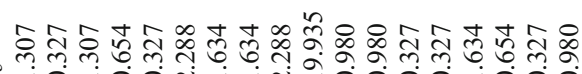

॰

咅

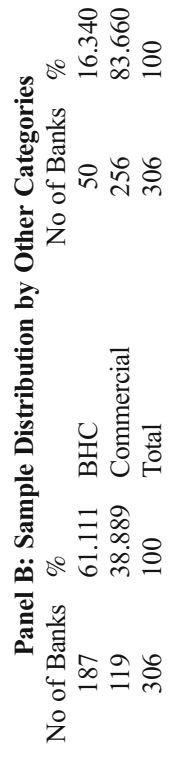

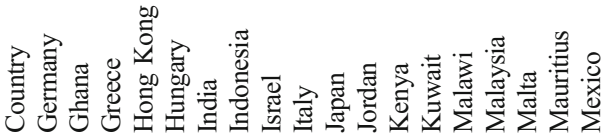

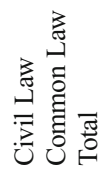

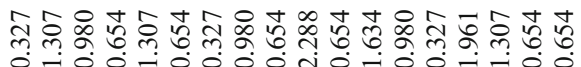

藏

छे हे

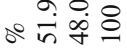

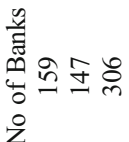

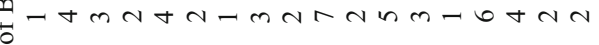

乙

ż

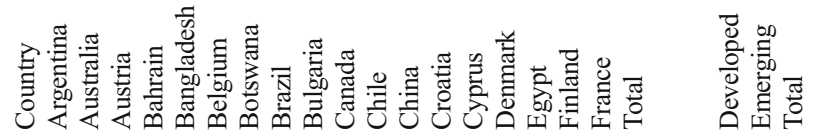


Where, $\mathrm{CFO}_{\mathrm{i},(\mathrm{t}+1)}$ is the cash flow from operations at time $\mathrm{t}+1\left(\mathrm{CFO}_{\mathrm{i},(\mathrm{t}+1)}\right.$ is the proxy used to test for earnings predictability). ROIA $A_{i, t}$ is the current profitability (return on operating income by average assets), $C G_{, i t}$ is a matrix of firm level corporate governance variables of bank $\mathrm{i}$ at time $t, \operatorname{ROIAA}_{i, t} * C G_{i, t}$ is the interaction term, $X_{i, t}$ is a matrix of firm-level control variables of bank $i$ at time $t, M E_{i t}$ is a matrix of country level macroeconomic variables at time $t, \varepsilon_{\mathrm{i}, \mathrm{t}}$ is the error term, $\alpha_{0}$ is the constant, and $\alpha, \beta, \gamma$ and $\delta$ are the vectors of coefficient estimates. All hypotheses are linked to the CG matrix, which includes board structure (board size, board independence), CEO power (CEO-duality, CEO-internal and CEO tenure) and risk governance (risk committee, chief risk officer and female directors) variables. In addition, IFRS, Big-4 audit firms, 1/Z-score (risk-taking), Tier-1 capital, deposit insurance, log total assets and GDP are used as control variables. The descriptions of these variables are shown in Table 2.

\section{Empirical results}

\subsection{Descriptive statistics and correlation matrix}

The summary statistics for earnings predictability, corporate and risk governance, and firm and country-level control variables are shown in Table 2. The panel data comprising observations for each bank span the 2007 to 2016 period and include 306 publicly-listed banks. The mean (median) of $\mathrm{CFO}_{\mathrm{t}+1}$ as the proxy for earnings predictability is 0.022 (0.019) indicating that average earnings predictability is positive. The mean (median) of current earnings is also $0.022(0.019)$. Similarly, the average value of an alternative proxy for earnings predictability - the standard deviation of the residuals $\left(v_{j}\right)$ from equation $\operatorname{Earn}_{\mathrm{j}, \mathrm{t}}=\phi_{0, \mathrm{j}}+\phi_{1, \mathrm{j}}$ Earn $_{\mathrm{j}, \mathrm{t}-\mathrm{1}}+\mathrm{v}_{\mathrm{j}, \mathrm{t}}$ deflated by firm $\mathrm{j}$ 's total assets (RESTDEV_ROIAA) - is 0.014 (0.010), which is also positive. Regarding the corporate governance variables, we find that mean board size is 12 and on average, independent directors constitute around $51 \%$ of board members. Again, about $24 \%$ of CEOs also have the co-role as Chairperson and almost $78 \%$ of them are internally promoted with an average tenure of 5 years. Turning to the risk governance variables, nearly $82 \%$ of the sample banks have risk committees and $49 \%$ have a CRO. The percentage of female directors is relatively low, approximately $10 \%$. For control variables, we find $54 \%$ of banks report their accounts under IFRS and $85 \%$ are audited by the Big- 4 audit firms. The mean inverse $\mathrm{Z}$-score ( $1 / \mathrm{Z}$ represents an insolvency risk measure), Tier 1 capital and deposit insurance variable for the sample are, respectively, 0.618, 0.093 and 0.404 . Finally, log total asset and log GDP size have mean values, respectively of, 17.061 and 27.315 .

The correlation matrix shows that current earnings, corporate governance, and risk governance variables typically have a positive relationship with $\mathrm{CFO}_{\mathrm{t}+1}$, (with the exceptions of our board independence and risk committee measures which suggest a negative link). ${ }^{5}$ Among the control variables, IFRS and total assets also have a negative link to $\mathrm{CFO}_{\mathrm{t}+1}$, and Big4 a positive relationship. The correlation matrix indicates no sign of serious multi-collinearity among the explanatory variables. ${ }^{6}$

\footnotetext{
${ }_{5}^{5}$ Available from the authors on request.

${ }^{6}$ None of the correlation coefficients are more than the $80 \%$ threshold, indicating an absence of multi-collinearity (Hair et al. 2006).
} 


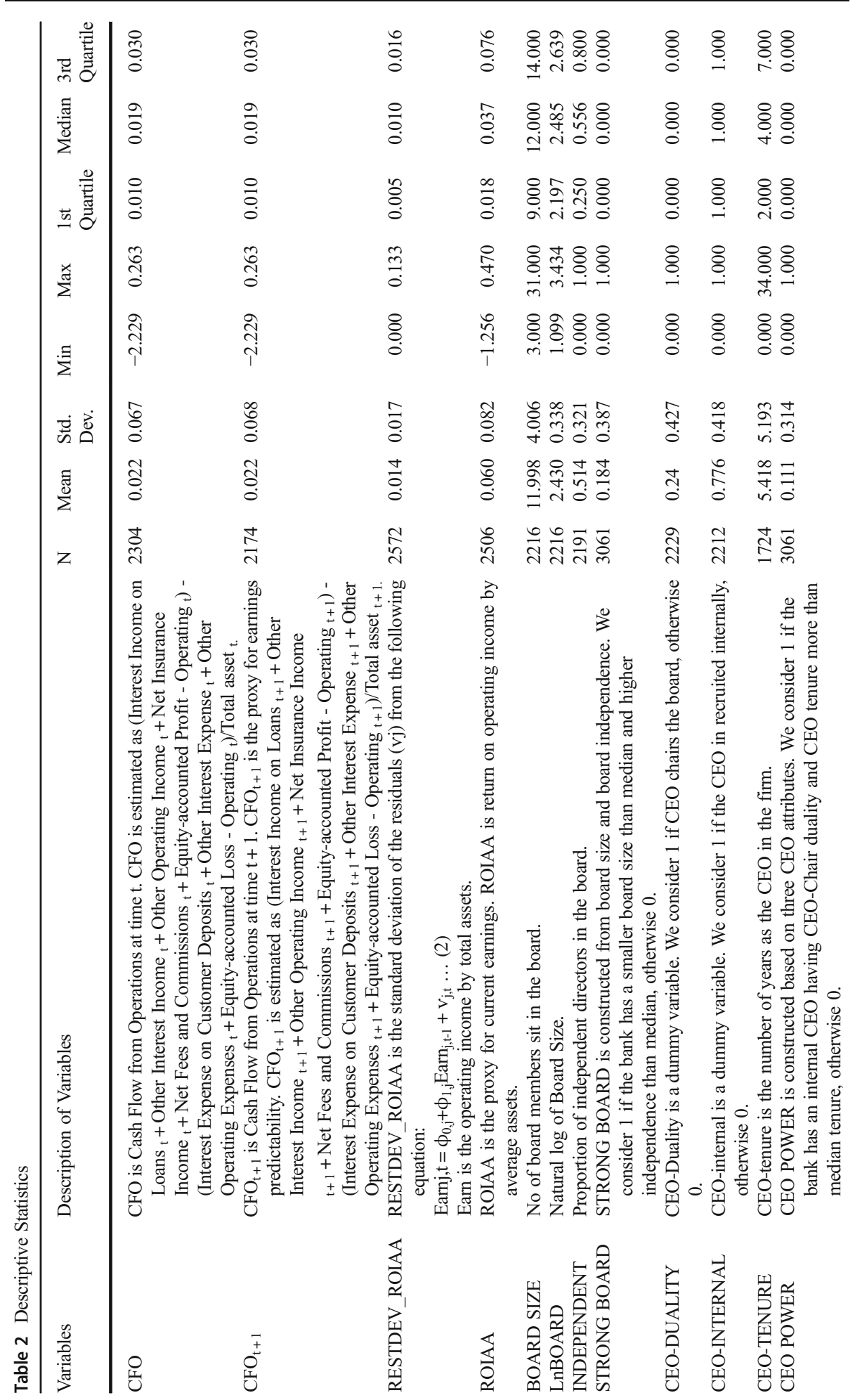




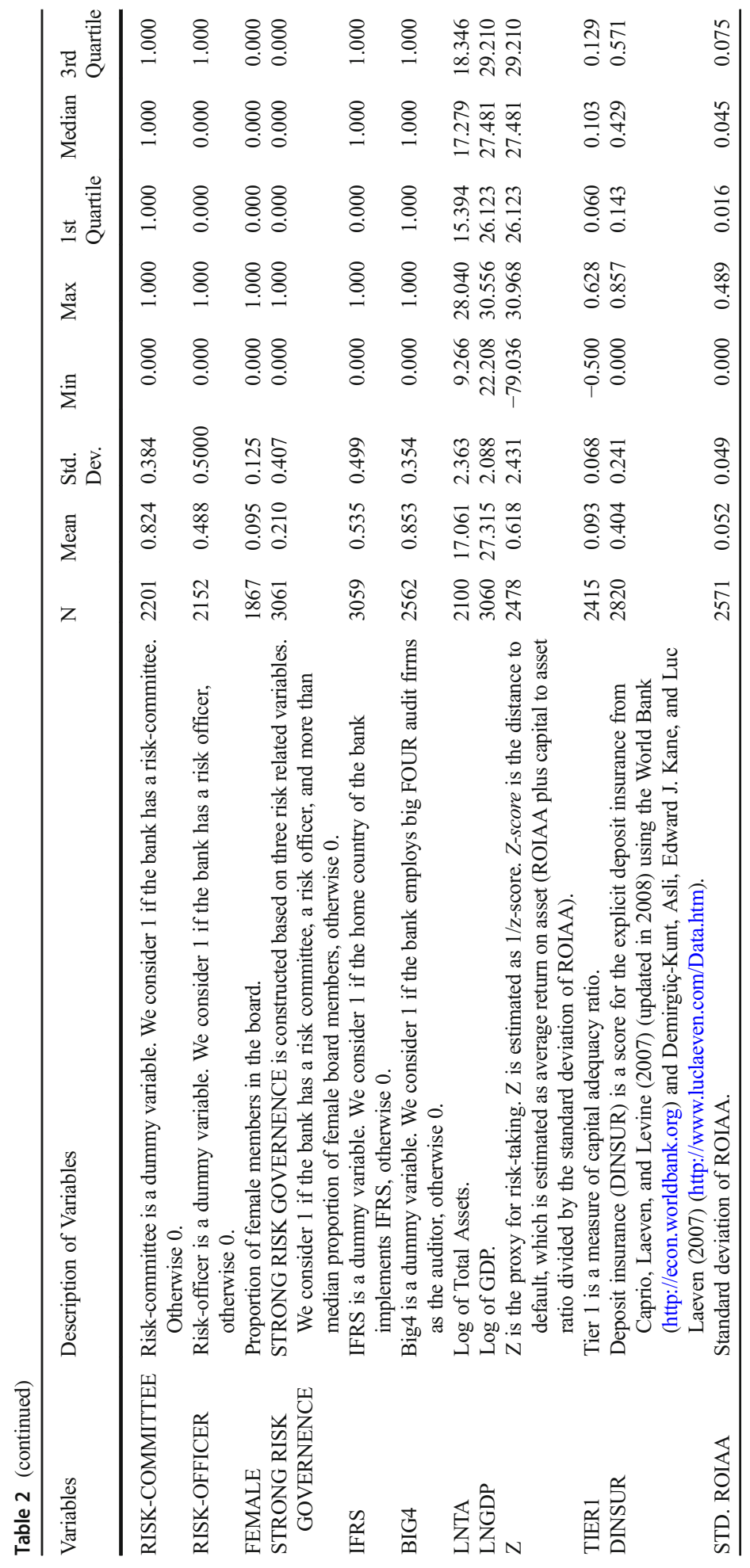


Table 3 Corporate Governance and Earnings Predictability

\begin{tabular}{|c|c|c|c|}
\hline Variables & Model 1 & Model 2 & Model 3 \\
\hline ROIAA & $\begin{array}{c}0.112 * \\
(1.68)\end{array}$ & $\begin{array}{c}0.123 * \\
(1.86)\end{array}$ & $\begin{array}{c}0.123 * \\
(1.86)\end{array}$ \\
\hline LNBOARD & $\begin{array}{c}0.007 * * \\
(2.11)\end{array}$ & $\begin{array}{c}0.008 * * \\
(2.53)\end{array}$ & $\begin{array}{c}0.008^{*} * \\
(2.53)\end{array}$ \\
\hline INDEPENDENT & $\begin{array}{c}-0.007 * \\
(-1.86)\end{array}$ & $\begin{array}{l}-0.005 \\
(-1.38)\end{array}$ & $\begin{array}{l}-0.005 \\
(-1.38)\end{array}$ \\
\hline CEO-DUALITY & $\begin{array}{l}0.003 \\
(0.93)\end{array}$ & $\begin{array}{l}0.003 \\
(1.12)\end{array}$ & $\begin{array}{l}0.003 \\
(1.12)\end{array}$ \\
\hline CEO-INTERNAL & $\begin{array}{l}0.002 \\
(0.76)\end{array}$ & $\begin{array}{l}0.001 \\
(0.10)\end{array}$ & $\begin{array}{l}0.001 \\
(0.10)\end{array}$ \\
\hline CEO-TENURE & $\begin{array}{l}-0.001 \\
(-0.81)\end{array}$ & $\begin{array}{l}-0.001 \\
(-0.81)\end{array}$ & $\begin{array}{l}-0.001 \\
(-0.81)\end{array}$ \\
\hline RISK-COMMITTEE & $\begin{array}{l}-0.003 \\
(-1.02)\end{array}$ & $\begin{array}{l}-0.003 \\
(-1.01)\end{array}$ & $\begin{array}{l}-0.003 \\
(-1.01)\end{array}$ \\
\hline RISK-OFFICER & $\begin{array}{l}0.001 \\
(0.46)\end{array}$ & $\begin{array}{l}0.001 \\
(0.18)\end{array}$ & $\begin{array}{l}0.001 \\
(0.18)\end{array}$ \\
\hline FEMALE & $\begin{array}{l}0.004 \\
(0.38)\end{array}$ & $\begin{array}{l}-0.002 \\
(-0.21)\end{array}$ & $\begin{array}{l}-0.002 \\
(-0.21)\end{array}$ \\
\hline ROIAA* LNBOARD & $\begin{array}{c}-0.052 * \\
(-1.92)\end{array}$ & $\begin{array}{c}-0.057 * * \\
(-2.12)\end{array}$ & $\begin{array}{c}-0.057 * * \\
(-2.12)\end{array}$ \\
\hline ROIAA*INDEPENDENT & $\begin{array}{c}0.083 * * \\
(2.53)\end{array}$ & $\begin{array}{c}0.068 * * \\
(2.06)\end{array}$ & $\begin{array}{c}0.068^{* *} \\
(2.06)\end{array}$ \\
\hline ROIAA*CEO-DUALITY & $\begin{array}{c}-0.066^{* * * *} \\
(-3.19)\end{array}$ & $\begin{array}{c}-0.065^{* * *} * \\
(-3.12)\end{array}$ & $\begin{array}{c}-0.065^{* * * *} \\
(-3.12)\end{array}$ \\
\hline ROIAA*CEO-INTERNAL & $\begin{array}{l}0.008 \\
(0.35)\end{array}$ & $\begin{array}{l}0.013 \\
(0.57)\end{array}$ & $\begin{array}{l}0.013 \\
(0.57)\end{array}$ \\
\hline ROIAA*CEO-TENURE & $\begin{array}{l}0.002 \\
(0.97)\end{array}$ & $\begin{array}{l}0.002 \\
(0.82)\end{array}$ & $\begin{array}{l}0.002 \\
(0.82)\end{array}$ \\
\hline ROIAA*RISK-COMMITTEE & $\begin{array}{c}0.11 \text { *** } \\
(4.25)\end{array}$ & $\begin{array}{c}0.11 * * * \\
(4.18)\end{array}$ & $\begin{array}{c}0.11 \text { *** } \\
(4.18)\end{array}$ \\
\hline ROIAA*RISK-OFFICER & $\begin{array}{c}-0.052 * * \\
(-2.34)\end{array}$ & $\begin{array}{c}-0.048 * * \\
(-2.20)\end{array}$ & $\begin{array}{c}-0.048 * * \\
(-2.20)\end{array}$ \\
\hline ROIAA*FEMALE & $\begin{array}{l}-0.011 \\
(-0.12)\end{array}$ & $\begin{array}{l}0.040 \\
(0.42)\end{array}$ & $\begin{array}{l}0.040 \\
(0.42)\end{array}$ \\
\hline IFRS & $\begin{array}{c}0.011 * * * \\
(4.33)\end{array}$ & $\begin{array}{c}0.011 * * * \\
(4.32)\end{array}$ & $\begin{array}{c}0.011 * * * \\
(4.32)\end{array}$ \\
\hline BIG4 & $\begin{array}{c}0.004^{*} \\
(1.84)\end{array}$ & $\begin{array}{l}0.003 \\
(1.54)\end{array}$ & $\begin{array}{l}0.003 \\
(1.54)\end{array}$ \\
\hline LNTA & $\begin{array}{c}-0.001 * * * \\
(-2.94)\end{array}$ & $\begin{array}{c}-0.002 * * * \\
(-4.15)\end{array}$ & $\begin{array}{c}-0.002 * * * \\
(-4.15)\end{array}$ \\
\hline LNGDP & $\begin{array}{c}-0.003 * * * \\
(-5.03)\end{array}$ & $\begin{array}{c}-0.003 * * * \\
(-4.47)\end{array}$ & $\begin{array}{c}-0.003 * * * \\
(-4.47)\end{array}$ \\
\hline $\mathrm{Z}$ & $\begin{array}{l}0.001 \\
(1.17)\end{array}$ & $\begin{array}{l}0.001 \\
(1.38)\end{array}$ & $\begin{array}{l}0.001 \\
(1.38)\end{array}$ \\
\hline TIER1 & $\begin{array}{c}0.090 * * * \\
(7.13)\end{array}$ & $\begin{array}{c}0.086^{* * *} * \\
(6.81)\end{array}$ & $\begin{array}{c}0.086 * * * \\
(6.81)\end{array}$ \\
\hline DINSUR & $\begin{array}{c}-0.020 * * * \\
(-5.56)\end{array}$ & $\begin{array}{c}-0.021 \text { *** } \\
(-6.05)\end{array}$ & $\begin{array}{c}-0.021 * * * \\
(-6.05)\end{array}$ \\
\hline BHC DUMMY & & $\begin{array}{c}0.008^{* * * *} \\
(3.54)\end{array}$ & $\begin{array}{c}0.008 * * * \\
(3.54)\end{array}$ \\
\hline STD. ROIAA & & $\begin{array}{l}0.028 \\
(1.31)\end{array}$ & $\begin{array}{l}0.028 \\
(1.31)\end{array}$ \\
\hline CRISIS DUMMY & & & $\begin{array}{l}-0.003 \\
(-0.75)\end{array}$ \\
\hline Constant & $\begin{array}{c}0.11 * * * \\
(6.23)\end{array}$ & $\begin{array}{c}0.11 * * * \\
(6.11)\end{array}$ & $\begin{array}{c}0.11 * * * \\
(6.11)\end{array}$ \\
\hline
\end{tabular}


Table 3 (continued)

\begin{tabular}{lccc}
\hline Variables & Model 1 & Model 2 & Model 3 \\
\hline Observations & 735 & 735 & 735 \\
R-squared & 0.37 & 0.38 & 0.38 \\
\hline
\end{tabular}

This Table reports the OLS regression results between earnings predictability, current earnings, and interactive corporate governance variables. The dependent variable is $\mathrm{CFO}_{\mathrm{t}+1}$. The variables descriptions are presented in Table 2. Standard errors in parentheses. *** $p<0.01$, ** $p<0.05, * p<0.1$

\subsection{Multivariate regression analysis}

\subsubsection{Corporate governance and earnings predictability}

Table 3 reports the results of regressions 1-3. Model 1 represents a base estimation of current earnings (ROIAA) and its interaction with corporate governance variables separately for board structure, CEO power and the risk governance variables. Models 2-3 include a couple of controls, such as whether the bank is a BHC or not and a dummy for the 2008-2009 financial crisis, respectively.

All three models in Table 3 reveal a positive and significant relationship between current earnings and $\mathrm{CFO}_{\mathrm{t}+1}$ (at the $10 \%$ level), indicating that the current year's reported earnings are an important predictor of future cash flow. These results confirm that quality earnings in the IFRS/GAAP framework have significant predictive power in determining bank $\mathrm{CFO}_{t+1}$. The finding is also consistent with Velury and Jenkins (2006) who show a positive and significant relationship between earnings and cash flows, as well as Atwood et al. (2010) who find that future cash flows are positively linked to current earnings.

Model 1 presents the effects of the interaction terms of current earnings and governance variables (namely, board size and independence; CEO-duality; CEO-internal and CEOtenure; risk committee; chief risk officer; and female director) on $\mathrm{CFO}_{\mathrm{t}+1}$. The results of the interaction variables are largely consistent with our main hypotheses suggesting a 'complementary' link between earnings and governance in explaining $\mathrm{CFO}_{\mathrm{t}+1}$. Firstly, on board structure variables (board size and independence), we find a significant negative relationship between $\mathrm{CFO}_{\mathrm{t}+1}$ and the interactive variable of accounting earnings and board size (ROIAA*LNBOARD) (10\% level) illustrating that a small bank board is capable of predicting future cash flows. Conversely, the interactive variable of accounting earnings and independent boards (ROIAA*INDEPENDENT) has a positive significant impact on $\mathrm{CFO}_{\mathrm{t}+1}(5 \%$ level$)$. So it appears that a small board with more independent directors helps predict future bank cash flows. The findings remain unchanged in all the models (Models 2-3), hence, our $\mathrm{H}_{1}$ is fully supported. The results are also consistent with those of AlDhamari and Ismail (2013) (although they contrast with those from Mashayekhi and Bazaz 2010).

Secondly, with respect to CEO power (CEO-duality, CEO-internal and CEO-tenure), we find (as expected) a negative relation between $\mathrm{CFO}_{\mathrm{t}+1}$ and the interactive variable of earnings and CEO-duality (5\% level). So CEO-duality reduces earnings quality / predictability. The variable that interacts earnings with $\mathrm{CEO}$-internal and CEO-tenure shows a positive but insignificant relation with $\mathrm{CFO}_{\mathrm{t}+1}$. These findings partially support our $\mathrm{H}_{2}$, and it seems that bank CEOs are more aligned to pursuing their own rather than the firms' interests. 
Finally, with regard to the risk governance variables (risk committee, chief risk officer and female director), we report mixed results for the effects of the variable that interacts earnings with the risk indicators and bank $\mathrm{CFO}_{\mathrm{t}+1}$. Consistent with expectations, we report that the risk committee interaction variable is positively associated with $\mathrm{CFO}_{\mathrm{t}+1}(1 \%$ level $)$, illustrating that it is capable of helping to improve earnings quality and hence predict future cash flow. However, the chief risk officer interaction variable reveals a significantly negative effect on $\mathrm{CFO}_{\mathrm{t}+1}$, (contrary to expectations), while the female director interaction variable has no significant relationship. These mixed findings lead us to marginally support our $\mathrm{H}_{3}$.

Again, both Model 2 and Model 3 extend the analysis of Model 1 with other control variables, respectively, for the effect of being a bank holding company (BHC) and during the period of the global financial crisis (2008-2009). In both models we observe that the results reflect those from Model 1 (for all interactive corporate governance and earnings variables) in terms of explaining $\mathrm{CFO}_{\mathrm{t}+1}$. In addition, Model 2, which includes the volatility in current earnings (std_roiaa) as an additional variable, also documents a positive significant effect of bank holding company status and future earnings, while there is a positive but insignificant effect of earnings volatility on $\mathrm{CFO}_{\mathrm{t}+1}$. Further tests also indicate no significant effects on future earnings, ${ }^{7}$ so volatility in current earnings is not an issue in determining future earnings. Furthermore, Model 3 also shows that there was no significant effect of the global financial crisis in terms of being able to predict future bank earnings over the sample period.

With regard to the control variables in Models 1-3, we observe consistent findings for the IFRS dummy and Tier 1 capital variable indicating a positive influence on $\mathrm{CFO}_{\mathrm{t}+1}$. The IFRS dummy has a positive link to $\mathrm{CFO}_{\mathrm{t}+1}$, which is consistent with expectations. The results also illustrate that capital adequacy, as a regulatory requirement and an indicator of bank solvency, is a predictor of future earnings. On the other hand, deposit insurance, bank size (total assets) and GDP variables show a negative relation with $\mathrm{CFO}_{\mathrm{t}+1}$. Even though deposit insurance is a safeguard to protect deposit holders, it lowers the ability to predict future $\mathrm{CFO}\left(\mathrm{CFO}_{\mathrm{t}+1}\right)$ perhaps reflecting the confounding effect of moral hazard on bank's future earnings. Similarly, smaller bank size and country GDP increases the predictive power of future earnings possibly because banking business is less complex in these countries. Finally, bank risk ( $\mathrm{z}$ score) does not explain future bank earnings across any of our estimates, while there is a positive significant relation between audit quality (Big-4 audit firms) and $\mathrm{CFO}_{\mathrm{t}+1}$ found in Model 1 only.

\subsubsection{Corporate governance indices and earnings predictability}

To check the validity of our earlier results (Table 3), we construct three corporate governance indices and conduct the regression analysis between the indices, their interactions with accounting earnings and earnings predictability $\left(\mathrm{CFO}_{\mathrm{t}+1}\right)$. We construct strong board, CEO power and strong risk governance based on corporate governance variables. ${ }^{8}$ Table 4 Models 1-3 show the relationship between the interacted governance and other control variables, respectively, with $\mathrm{CFO}_{\mathrm{t}+1}$.

\footnotetext{
${ }_{7}^{7}$ The results are not reported due to space, but are available on request.

8 'Strong board' is defined as having a board size (number of members) lower than the median and a greater than median number of independent directors. CEO power is defined as having an internally appointed CEO that plays a dual role and who has board tenure higher than median. Similarly, strong risk governance is defined as having both a risk committee and risk officer as well as having a greater than median number of female board members.
} 
Table 4 Corporate Governance Indices and Earnings Predictability

\begin{tabular}{|c|c|c|c|}
\hline Variables & Model 1 & Model 2 & Model 3 \\
\hline ROIAA & $\begin{array}{c}0.343 * * * \\
(9.85)\end{array}$ & $\begin{array}{c}0.356^{* * * *} \\
(11.02)\end{array}$ & $\begin{array}{c}0.356^{* * * *} \\
(11.02)\end{array}$ \\
\hline STRONG-BOARD & $\begin{array}{l}0.010 \\
(1.62)\end{array}$ & $\begin{array}{l}0.004 \\
(0.62)\end{array}$ & $\begin{array}{l}0.004 \\
(0.62)\end{array}$ \\
\hline CEO-POWER & $\begin{array}{l}0.012 \\
(1.47)\end{array}$ & $\begin{array}{l}0.011 \\
(1.46)\end{array}$ & $\begin{array}{l}0.011 \\
(1.46)\end{array}$ \\
\hline STRONG-RISK-GOVERNANCE & $\begin{array}{c}0.016 * * * \\
(2.86)\end{array}$ & $\begin{array}{c}0.017 * * * \\
(3.27)\end{array}$ & $\begin{array}{c}0.017 * * * \\
(3.27)\end{array}$ \\
\hline ROIAA*STRONG-BOARD & $\begin{array}{l}-0.13^{*} \\
(-1.89)\end{array}$ & $\begin{array}{l}-0.053 \\
(-0.86)\end{array}$ & $\begin{array}{l}-0.053 \\
(-0.86)\end{array}$ \\
\hline ROIAA*CEO-POWER & $\begin{array}{c}-0.201 * * * \\
(-3.14)\end{array}$ & $\begin{array}{c}-0.155^{* * * *} \\
(-2.61)\end{array}$ & $\begin{array}{c}-0.155 * * * \\
(-2.61)\end{array}$ \\
\hline ROIAA-STRONG-RISK-GOVERNANCE & $\begin{array}{c}-0.202 * * * \\
(-3.70)\end{array}$ & $\begin{array}{c}-0.241 * * * \\
(-4.77)\end{array}$ & $\begin{array}{c}-0.241 * * * \\
(-4.77)\end{array}$ \\
\hline IFRS & $\begin{array}{l}0.002 \\
(0.39)\end{array}$ & $\begin{array}{l}-0.003 \\
(-0.65)\end{array}$ & $\begin{array}{l}-0.003 \\
(-0.65)\end{array}$ \\
\hline BIG4 & $\begin{array}{l}-0.005 \\
(-0.86)\end{array}$ & $\begin{array}{l}0.003 \\
(0.59)\end{array}$ & $\begin{array}{l}0.003 \\
(0.59)\end{array}$ \\
\hline LNTA & $\begin{array}{l}0.001 \\
(0.61)\end{array}$ & $\begin{array}{c}0.005^{* * * *} \\
(4.29)\end{array}$ & $\begin{array}{c}0.005 * * * \\
(4.29)\end{array}$ \\
\hline LNGDP & $\begin{array}{l}-0.002 * \\
(-1.84)\end{array}$ & $\begin{array}{l}0.001 \\
(0.69)\end{array}$ & $\begin{array}{l}0.001 \\
(0.69)\end{array}$ \\
\hline Z & $\begin{array}{l}0.001 \\
(0.90)\end{array}$ & $\begin{array}{c}0.003 * * * \\
(2.77)\end{array}$ & $\begin{array}{c}0.003 * * * \\
(2.77)\end{array}$ \\
\hline TIER1 & $\begin{array}{l}0.060^{*} \\
(1.94)\end{array}$ & $\begin{array}{c}0.062 * * \\
(2.17)\end{array}$ & $\begin{array}{c}0.062^{* * *} \\
(2.17)\end{array}$ \\
\hline DINSUR & $\begin{array}{l}-0.008 \\
(-0.97)\end{array}$ & $\begin{array}{l}-0.006 \\
(-0.71)\end{array}$ & $\begin{array}{l}-0.006 \\
(-0.71)\end{array}$ \\
\hline BHC DUMMY & & $\begin{array}{l}0.006 \\
(1.14)\end{array}$ & $\begin{array}{l}0.006 \\
(1.14)\end{array}$ \\
\hline STD. ROIAA & & $\begin{array}{c}-0.738 * * * \\
(-15.18)\end{array}$ & $\begin{array}{c}-0.738 * * * \\
(-15.18)\end{array}$ \\
\hline CRISIS DUMMY & & & $\begin{array}{l}-0.011 \\
(-1.05)\end{array}$ \\
\hline Constant & $\begin{array}{l}0.058 \\
(1.53)\end{array}$ & $\begin{array}{c}-0.067^{*} \\
(-1.85)\end{array}$ & $\begin{array}{c}-0.068 * \\
(-1.85)\end{array}$ \\
\hline Observations & 1407 & 1407 & 1407 \\
\hline R-squared & 0.08 & 0.22 & 0.22 \\
\hline
\end{tabular}

This Table reports the OLS regression results between earnings predictability, current earnings, and interactive strong-board, CEO-power, and risk-governance variables. The dependent variable is $\mathrm{CFO}_{\mathrm{t}+1}$. The variables descriptions are presented in Table 2. Standard errors in parentheses. *** $\mathrm{p}<0.01$, ** $\mathrm{p}<0.05$, $* \mathrm{p}<0.1$

Table 4 reveals a strong positive and significant relationship between current earnings and $\mathrm{CFO}_{\mathrm{t}+1}$ at the $1 \%$ level across the three models thus reinforcing that the current year's reported earnings is an important predictor of future cash flow. In Model 1 of Table 4, the strong board index interactive variable shows a negative effect on $\mathrm{CFO}_{\mathrm{t}+1}(10 \%$ level). This moderately supports our findings in Table 3 and $\mathrm{H}_{1}$, implying that current earnings and strong boards have sufficient explanatory power to determine future earnings. With regard to our CEO power index interactive variable we also find a strong negative and significant relation with $\mathrm{CFO}_{\mathrm{t}+1}$ at the $1 \%$ level (in contrast to Table 3 findings). Therefore, $\mathrm{H}_{2}$ is fully supported, namely that powerful bank CEOs tend to pursue their own interests over firms' interest and this is reflected in less predictable (poorer quality) future earnings. As for strong risk governance we find a 
Table 5 Corporate Governance and Earnings Predictability (Civil Law vs. Common Law Countries)

\begin{tabular}{|c|c|c|c|c|c|c|}
\hline & \multicolumn{3}{|c|}{ Civil Law Countries } & \multicolumn{3}{|c|}{ Common Law Countries } \\
\hline & Panel A & & & Panel B & & \\
\hline Variables & Model 1 & Model 2 & Model 3 & Model 1 & Model 2 & Model 3 \\
\hline ROIAA & $\begin{array}{c}0.163 * * \\
(2.08)\end{array}$ & $\begin{array}{c}0.148^{*} \\
(1.96)\end{array}$ & $\begin{array}{c}0.148^{*} \\
(1.96)\end{array}$ & $\begin{array}{l}0.185 \\
(1.31)\end{array}$ & $\begin{array}{c}0.236^{*} \\
(1.68)\end{array}$ & $\begin{array}{c}0.236^{*} \\
(1.68)\end{array}$ \\
\hline LNBOARD & $\begin{array}{c}0.006 * \\
(1.85)\end{array}$ & $\begin{array}{c}0.007 * * \\
(2.02)\end{array}$ & $\begin{array}{c}0.007 * * \\
(2.02)\end{array}$ & $\begin{array}{c}0.004 \\
(0.57)\end{array}$ & $\begin{array}{l}0.006 \\
(0.93)\end{array}$ & $\begin{array}{l}0.006 \\
(0.93)\end{array}$ \\
\hline INDEPENDENT & $\begin{array}{c}-0.007 * \\
(-1.65)\end{array}$ & $\begin{array}{c}-0.007 * \\
(-1.65)\end{array}$ & $\begin{array}{c}-0.007 * \\
(-1.65)\end{array}$ & $\begin{array}{l}-0.006 \\
(-0.91)\end{array}$ & $\begin{array}{l}-0.003 \\
(-0.49)\end{array}$ & $\begin{array}{l}-0.003 \\
(-0.49)\end{array}$ \\
\hline CEO-DUALITY & $\begin{array}{l}-0.002 \\
(-0.55)\end{array}$ & $\begin{array}{l}-0.005 \\
(-1.53)\end{array}$ & $\begin{array}{l}-0.005 \\
(-1.53)\end{array}$ & $\begin{array}{l}0.005 \\
(1.04)\end{array}$ & $\begin{array}{l}0.006 \\
(1.23)\end{array}$ & $\begin{array}{l}0.006 \\
(1.23)\end{array}$ \\
\hline CEO-INTERNAL & $\begin{array}{l}0.003 \\
(0.99)\end{array}$ & $\begin{array}{l}0.002 \\
(0.72)\end{array}$ & $\begin{array}{c}0.0025 \\
(0.72)\end{array}$ & $\begin{array}{l}0.002 \\
(0.42)\end{array}$ & $\begin{array}{l}0.001 \\
(0.04)\end{array}$ & $\begin{array}{l}0.001 \\
(0.03)\end{array}$ \\
\hline CEO-TENURE & $\begin{array}{l}0.001 \\
(0.57)\end{array}$ & $\begin{array}{l}0.001 \\
(1.18)\end{array}$ & $\begin{array}{l}0.001 \\
(1.18)\end{array}$ & $\begin{array}{l}-0.001 \\
(-1.18)\end{array}$ & $\begin{array}{l}-0.001 \\
(-0.84)\end{array}$ & $\begin{array}{l}-0.001 \\
(-0.84)\end{array}$ \\
\hline RISK-COMMITTEE & $\begin{array}{l}-0.002 \\
(-0.58)\end{array}$ & $\begin{array}{l}-0.004 \\
(-1.27)\end{array}$ & $\begin{array}{l}-0.004 \\
(-1.27)\end{array}$ & $\begin{array}{c}-0.008^{*} \\
(-1.67)\end{array}$ & $\begin{array}{l}-0.007 \\
(-1.46)\end{array}$ & $\begin{array}{l}-0.007 \\
(-1.46)\end{array}$ \\
\hline RISK-OFFICER & $\begin{array}{l}-0.003 \\
(-1.17)\end{array}$ & $\begin{array}{l}-0.001 \\
(-0.47)\end{array}$ & $\begin{array}{l}-0.001 \\
(-0.47)\end{array}$ & $\begin{array}{c}0.0103 * * \\
(2.36)\end{array}$ & $\begin{array}{c}0.010 * * \\
(2.26)\end{array}$ & $\begin{array}{c}0.010 * * \\
(2.26)\end{array}$ \\
\hline FEMALE & $\begin{array}{l}-0.007 \\
(-0.65)\end{array}$ & $\begin{array}{l}-0.008 \\
(-0.75)\end{array}$ & $\begin{array}{l}-0.008 \\
(-0.75)\end{array}$ & $\begin{array}{l}0.021 \\
(0.92)\end{array}$ & $\begin{array}{l}0.010 \\
(0.45)\end{array}$ & $\begin{array}{l}0.010 \\
(0.45)\end{array}$ \\
\hline ROIAA* LNBOARD & $\begin{array}{c}-0.056^{*} \\
(-1.93)\end{array}$ & $\begin{array}{c}-0.064 * * \\
(-2.29)\end{array}$ & $\begin{array}{c}-0.064 * * \\
(-2.29)\end{array}$ & $\begin{array}{l}-0.056 \\
(-0.88)\end{array}$ & $\begin{array}{l}-0.078 \\
(-1.23)\end{array}$ & $\begin{array}{l}-0.078 \\
(-1.23)\end{array}$ \\
\hline ROIAA*INDEPENDENT & $\begin{array}{c}0.104 * * \\
(2.34)\end{array}$ & $\begin{array}{c}0.075^{*} \\
(1.73)\end{array}$ & $\begin{array}{c}0.075^{*} \\
(1.73)\end{array}$ & $\begin{array}{l}0.058 \\
(1.07)\end{array}$ & $\begin{array}{l}0.048 \\
(0.87)\end{array}$ & $\begin{array}{l}0.048 \\
(0.87)\end{array}$ \\
\hline ROIAA*CEO-DUALITY & $\begin{array}{l}-0.014 \\
(-0.49)\end{array}$ & $\begin{array}{l}0.025 \\
(0.86)\end{array}$ & $\begin{array}{l}0.025 \\
(0.86)\end{array}$ & $\begin{array}{c}-0.098 * * * \\
(-2.91)\end{array}$ & $\begin{array}{c}-0.099 * * * \\
(-2.97)\end{array}$ & $\begin{array}{c}-0.099 * * * \\
(-2.97)\end{array}$ \\
\hline ROIAA*CEO-INTERNAL & $\begin{array}{c}-0.071 * \\
(-1.93)\end{array}$ & $\begin{array}{l}-0.058 \\
(-1.62)\end{array}$ & $\begin{array}{l}-0.058 \\
(-1.62)\end{array}$ & $\begin{array}{l}-0.005 \\
(-0.14)\end{array}$ & $\begin{array}{c}-0.002 \\
(-0.047)\end{array}$ & $\begin{array}{c}-0.002 \\
(-0.047)\end{array}$ \\
\hline ROIAA*CEO-TENURE & $\begin{array}{l}-0.001 \\
(-0.18)\end{array}$ & $\begin{array}{l}-0.002 \\
(-0.72)\end{array}$ & $\begin{array}{c}-0.00207 \\
(-0.718)\end{array}$ & $\begin{array}{c}0.00255 \\
(0.942)\end{array}$ & $\begin{array}{c}0.00199 \\
(0.745)\end{array}$ & $\begin{array}{c}0.00199 \\
(0.745)\end{array}$ \\
\hline ROIAA*RISK-COMMITTEE & $\begin{array}{l}0.018 \\
(0.58)\end{array}$ & $\begin{array}{l}0.045 \\
(1.47)\end{array}$ & $\begin{array}{l}0.045 \\
(1.47)\end{array}$ & $\begin{array}{c}0.238^{* * *} \\
(4.57)\end{array}$ & $\begin{array}{c}0.238^{* * * *} \\
(4.61)\end{array}$ & $\begin{array}{c}0.238 * * * \\
(4.61)\end{array}$ \\
\hline ROIAA*RISK-OFFICER & $\begin{array}{c}0.0530^{*} \\
(1.774)\end{array}$ & $\begin{array}{l}0.0394 \\
(1.364)\end{array}$ & $\begin{array}{l}0.0394 \\
(1.364)\end{array}$ & $\begin{array}{c}-0.229 * * * \\
(-5.606)\end{array}$ & $\begin{array}{c}-0.225 * * * \\
(-5.610)\end{array}$ & $\begin{array}{c}-0.225^{* * *} * \\
(-5.610)\end{array}$ \\
\hline ROIAA*FEMALE & $\begin{array}{c}-0.11 \\
(-0.861)\end{array}$ & $\begin{array}{c}-0.066 \\
(-0.515)\end{array}$ & $\begin{array}{c}-0.066 \\
(-0.515)\end{array}$ & $\begin{array}{l}0.121 \\
(0.73)\end{array}$ & $\begin{array}{l}0.190 \\
(1.14)\end{array}$ & $\begin{array}{l}0.190 \\
(1.14)\end{array}$ \\
\hline IFRS & $\begin{array}{l}0.005 \\
(1.37)\end{array}$ & $\begin{array}{c}0.008 * * \\
(2.24)\end{array}$ & $\begin{array}{c}0.008 * * \\
(2.24)\end{array}$ & $\begin{array}{c}0.010^{* * * *} \\
(2.68)\end{array}$ & $\begin{array}{c}0.008^{* *} * \\
(2.04)\end{array}$ & $\begin{array}{c}0.008 * * \\
(2.04)\end{array}$ \\
\hline BIG4 & $\begin{array}{l}-0.002 \\
(-0.56)\end{array}$ & $\begin{array}{l}-0.004 \\
(-1.219)\end{array}$ & $\begin{array}{l}-0.004 \\
(-1.22)\end{array}$ & $\begin{array}{l}0.003 \\
(0.92)\end{array}$ & $\begin{array}{l}0.002 \\
(0.61)\end{array}$ & $\begin{array}{l}0.002 \\
(0.61)\end{array}$ \\
\hline LNTA & $\begin{array}{c}-0.002 * * \\
(-2.16)\end{array}$ & $\begin{array}{c}-0.003 * * * \\
(-3.62)\end{array}$ & $\begin{array}{c}-0.003 * * * \\
(-3.62)\end{array}$ & $\begin{array}{l}-0.001 * \\
(-1.82)\end{array}$ & $\begin{array}{c}-0.001 * * \\
(-2.17)\end{array}$ & $\begin{array}{c}-0.001 * * \\
(-2.17)\end{array}$ \\
\hline LNGDP & $\begin{array}{c}-0.003 * * * \\
(-3.36)\end{array}$ & $\begin{array}{c}-0.002 * * * \\
(-2.99)\end{array}$ & $\begin{array}{c}-0.002 * * * \\
(-2.99)\end{array}$ & $\begin{array}{c}-0.002 * * \\
(-2.50)\end{array}$ & $\begin{array}{c}-0.003 * * \\
(-2.58)\end{array}$ & $\begin{array}{c}-0.003 * * \\
(-2.58)\end{array}$ \\
\hline Z & $\begin{array}{l}0.001 \\
(1.22)\end{array}$ & $\begin{array}{l}0.001 \\
(1.02)\end{array}$ & $\begin{array}{l}0.001 \\
(1.02)\end{array}$ & $\begin{array}{l}0.002 \\
(1.25)\end{array}$ & $\begin{array}{l}0.001 \\
(0.69)\end{array}$ & $\begin{array}{l}0.001 \\
(0.69)\end{array}$ \\
\hline TIER1 & $\begin{array}{c}0.051 * * * \\
(2.77)\end{array}$ & $\begin{array}{c}0.054 * * * \\
(3.10)\end{array}$ & $\begin{array}{c}0.054 * * * \\
(3.10)\end{array}$ & $\begin{array}{c}0.128 * * * \\
(6.67)\end{array}$ & $\begin{array}{c}0.12 * * * \\
(6.03)\end{array}$ & $\begin{array}{c}0.12 * * * \\
(6.03)\end{array}$ \\
\hline DINSUR & $\begin{array}{c}-0.052 * * * \\
(-7.18)\end{array}$ & $\begin{array}{c}-0.058 * * * \\
(-8.05)\end{array}$ & $\begin{array}{c}-0.0580 * * * \\
(-8.05)\end{array}$ & $\begin{array}{l}-0.003 \\
(-0.66)\end{array}$ & $\begin{array}{l}-0.006 \\
(-1.10)\end{array}$ & $\begin{array}{l}-0.006 \\
(-1.10)\end{array}$ \\
\hline BHC DUMMY & & $\begin{array}{l}0.003 \\
(0.71)\end{array}$ & $\begin{array}{l}0.003 \\
(0.71)\end{array}$ & & $\begin{array}{c}0.012 * * * \\
(3.63)\end{array}$ & $\begin{array}{c}0.012 * * * \\
(3.63)\end{array}$ \\
\hline STD. ROIAA & & $\begin{array}{c}0.168 * * * \\
(5.18)\end{array}$ & $\begin{array}{c}0.168 * * * \\
(5.18)\end{array}$ & & $\begin{array}{l}0.001 \\
(0.03)\end{array}$ & $\begin{array}{l}0.001 \\
(0.03)\end{array}$ \\
\hline CRISIS DUMMY & & & -0.003 & & & 0.001 \\
\hline
\end{tabular}


Table 5 (continued)

\begin{tabular}{|c|c|c|c|c|c|c|}
\hline & \multicolumn{3}{|c|}{ Civil Law Countries } & \multicolumn{3}{|c|}{ Common Law Countries } \\
\hline & Panel A & & & Panel B & & \\
\hline \multirow[b]{2}{*}{ Constant } & & & $(-0.69)$ & & & $(0.05)$ \\
\hline & $\begin{array}{c}0.128 * * * \\
(5.88)\end{array}$ & $\begin{array}{c}0.144 * * * \\
(6.64)\end{array}$ & $\begin{array}{c}0.144 * * * \\
(6.64)\end{array}$ & $\begin{array}{c}0.0866^{* * *} * \\
(2.60)\end{array}$ & $\begin{array}{c}0.088^{*} * * \\
(2.63)\end{array}$ & $\begin{array}{c}0.088^{* * * *} \\
(2.63)\end{array}$ \\
\hline Observations & 341 & 341 & 341 & 378 & 378 & 378 \\
\hline R-squared & 0.40 & 0.45 & 0.45 & 0.49 & 0.51 & 0.51 \\
\hline
\end{tabular}

This Table reports the OLS regression results between earnings predictability, current earnings, and interactive corporate governance variables in the Civil Law and Common Law countries. The dependent variable is $\mathrm{CFO}_{t+1}$. The variables descriptions are presented in Table 2. Panel A reports the effect of current earnings and interactive corporate governance variables on $\mathrm{CFO}_{\mathrm{t}+1}$ in Civil Law countries. Panel B reports the effect of current earnings and interactive corporate governance variables on $\mathrm{CFO}_{\mathrm{t}+1}$ in Common Law countries. Standard errors in parentheses. $* * * \mathrm{p}<0.01, * * \mathrm{p}<0.05, * \mathrm{p}<0.1$

negative significant influence on $\mathrm{CFO}_{\mathrm{t}+1}$ at the $1 \%$ level, indicating risk governance mechanisms are not effective in predicting future earnings. Therefore, $\mathrm{H}_{3}$ is not supported. Looking at the remaining estimates and the influence of other controls we mainly find qualitatively similar results in Table 4 as in Table 3.

\subsubsection{Corporate governance and earnings predictability in different legal jurisdictions (common law versus civil law countries)}

Following Table 4 Models 1-3, we re-estimate similar models after splitting the sample into banks based in common or civil law countries. The results are reported in Tables 5 Models 1-3 of Panels A and Panel B. In Panel A estimates for the civil law countries are reported and here we see that the interactions variables with current earnings reveal findings as reported in Table 4 for board structure variables but not for CEO power and risk governance variables. In Panel B of Table 5 the findings for banks operating in common law countries shows that CEO power and risk governance variables (but not board structure) improve cash flow prediction. In sum, the findings for common law countries generally confirm our earlier findings reported in Table 3. Clearly there are legal differences across countries that influence the effectiveness of governance mechanisms in enhancing bank earnings quality.

\subsubsection{Corporate governance and earnings predictability for banks operating in developed and emerging countries, and for institutions of varying size}

In Table 6 (Models 1-3 of Panels A and B), we re-estimate the same regression after splitting the sample based on countries' state of economic development (developed vs. emerging) from the IMF definition. Panel A reports the results for banks operating in developed countries where the board structure interaction variables with current earnings (rather than CEO power and risk governance structure interaction indicators with current earnings) are found to have a significant influence on future cash flows. We find that both CEO-duality and female directors have a positive link to $\mathrm{CFO}_{\mathrm{t}+1}$, suggesting that bank CEOs and female directors are more likely to provide positive signals to the market to maintain sustained earnings for banks. In 
Table 6 Corporate Governance and Earnings Predictability (Developed Vs. Emerging Countries)

\begin{tabular}{|c|c|c|c|c|c|c|}
\hline & \multicolumn{3}{|c|}{ Developed Countries } & \multicolumn{3}{|c|}{ Emerging Countries } \\
\hline & Panel A & & & Panel B & & \\
\hline Variables & Model 1 & Model 2 & Model 3 & Model 1 & Model 2 & Model 3 \\
\hline ROIAA & $\begin{array}{l}0.082 \\
(1.39)\end{array}$ & $\begin{array}{l}0.085 \\
(1.44)\end{array}$ & $\begin{array}{l}0.085 \\
(1.44)\end{array}$ & $\begin{array}{c}1.084 * * * \\
(5.27)\end{array}$ & $\begin{array}{c}1.136^{* * * *} \\
(5.62)\end{array}$ & $\begin{array}{c}1.136^{* * * *} \\
(5.62)\end{array}$ \\
\hline LNBOARD & $\begin{array}{l}0.001 \\
(0.32)\end{array}$ & $\begin{array}{l}0.001 \\
(0.32)\end{array}$ & $\begin{array}{l}0.001 \\
(0.32)\end{array}$ & $\begin{array}{l}0.007 \\
(0.98)\end{array}$ & $\begin{array}{l}0.008 \\
(1.04)\end{array}$ & $\begin{array}{l}0.008 \\
(1.04)\end{array}$ \\
\hline INDEPENDENT & $\begin{array}{l}0.004 \\
(1.42)\end{array}$ & $\begin{array}{l}0.005 \\
(1.54)\end{array}$ & $\begin{array}{l}0.005 \\
(1.54)\end{array}$ & $\begin{array}{l}0.009 \\
(1.25)\end{array}$ & $\begin{array}{l}0.006 \\
(0.77)\end{array}$ & $\begin{array}{c}0.0056 \\
(0.77)\end{array}$ \\
\hline CEO-DUALITY & $\begin{array}{c}-0.007 * * * \\
(-2.73)\end{array}$ & $\begin{array}{c}-0.007 * * * \\
(-3.08)\end{array}$ & $\begin{array}{c}-0.007 * * * \\
(-3.08)\end{array}$ & $\begin{array}{c}0.031 * * * \\
(5.74)\end{array}$ & $\begin{array}{c}0.032 * * * \\
(5.87)\end{array}$ & $\begin{array}{c}0.032 * * * \\
(5.87)\end{array}$ \\
\hline CEO-INTERNAL & $\begin{array}{l}0.001 \\
(0.44)\end{array}$ & $\begin{array}{l}0.001 \\
(0.36)\end{array}$ & $\begin{array}{l}0.001 \\
(0.36)\end{array}$ & $\begin{array}{c}0.010^{*} \\
(1.78)\end{array}$ & $\begin{array}{c}0.012 * * \\
(2.01)\end{array}$ & $\begin{array}{c}0.012 * * \\
(2.01)\end{array}$ \\
\hline CEO-TENURE & $\begin{array}{l}0.001 \\
(1.47)\end{array}$ & $\begin{array}{l}0.001^{*} \\
(1.69)\end{array}$ & $\begin{array}{c}0.001 * \\
(1.69)\end{array}$ & $\begin{array}{l}-0.001 \\
(-0.67)\end{array}$ & $\begin{array}{l}0.001 \\
(0.13)\end{array}$ & $\begin{array}{l}0.001 \\
(0.13)\end{array}$ \\
\hline RISK-COMMITTEE & $\begin{array}{l}0.001 \\
(0.39)\end{array}$ & $\begin{array}{l}0.001 \\
(0.12)\end{array}$ & $\begin{array}{l}0.001 \\
(0.12)\end{array}$ & $\begin{array}{c}-0.022 * * * \\
(-3.36)\end{array}$ & $\begin{array}{c}-0.024 * * * \\
(-3.69)\end{array}$ & $\begin{array}{c}-0.024 * * * \\
(-3.69)\end{array}$ \\
\hline RISK-OFFICER & $\begin{array}{l}-0.003 \\
(-1.36)\end{array}$ & $\begin{array}{l}-0.003 \\
(-1.48)\end{array}$ & $\begin{array}{l}-0.003 \\
(-1.48)\end{array}$ & $\begin{array}{c}0.0043 \\
(1.02)\end{array}$ & $\begin{array}{l}0.004 \\
(0.91)\end{array}$ & $\begin{array}{l}0.004 \\
(0.91)\end{array}$ \\
\hline FEMALE & $\begin{array}{c}-0.015^{*} \\
(-1.92)\end{array}$ & $\begin{array}{c}-0.014 * \\
(-1.81)\end{array}$ & $\begin{array}{c}-0.014 * \\
(-1.81)\end{array}$ & $\begin{array}{l}-0.002 \\
(-0.10)\end{array}$ & $\begin{array}{l}-0.006 \\
(-0.28)\end{array}$ & $\begin{array}{l}-0.006 \\
(-0.28)\end{array}$ \\
\hline ROIAA* LNBOARD & $\begin{array}{l}-0.037 \\
(-1.64)\end{array}$ & $\begin{array}{l}-0.041 * \\
(-1.79)\end{array}$ & $\begin{array}{c}-0.041 * \\
(-1.79)\end{array}$ & $\begin{array}{l}-0.146 \\
(-1.14)\end{array}$ & $\begin{array}{l}-0.174 \\
(-1.38)\end{array}$ & $\begin{array}{l}-0.174 \\
(-1.38)\end{array}$ \\
\hline ROIAA*INDEPENDENT & $\begin{array}{l}0.016 \\
(0.65)\end{array}$ & $\begin{array}{l}0.009 \\
(0.38)\end{array}$ & $\begin{array}{l}0.009 \\
(0.38)\end{array}$ & $\begin{array}{l}-0.215^{*} \\
(-1.91)\end{array}$ & $\begin{array}{l}-0.156 \\
(-1.40)\end{array}$ & $\begin{array}{l}-0.156 \\
(-1.40)\end{array}$ \\
\hline ROIAA*CEO-DUALITY & $\begin{array}{c}0.033 * * \\
(2.06)\end{array}$ & $\begin{array}{c}0.040 * * \\
(2.50)\end{array}$ & $\begin{array}{c}0.040 * * \\
(2.50)\end{array}$ & $\begin{array}{c}-0.560 * * * \\
(-7.59)\end{array}$ & $\begin{array}{c}-0.546 * * * \\
(-7.39)\end{array}$ & $\begin{array}{c}-0.546 * * * \\
(-7.39)\end{array}$ \\
\hline ROIAA*CEO-INTERNAL & $\begin{array}{l}-0.011 \\
(-0.69)\end{array}$ & $\begin{array}{l}-0.007 \\
(-0.45)\end{array}$ & $\begin{array}{l}-0.007 \\
(-0.45)\end{array}$ & $\begin{array}{c}-0.303 * * * \\
(-3.17)\end{array}$ & $\begin{array}{c}-0.332 * * * \\
(-3.54)\end{array}$ & $\begin{array}{c}-0.332 * * * \\
(-3.54)\end{array}$ \\
\hline ROIAA*CEO-TENURE & $\begin{array}{l}-0.001 \\
(-0.54)\end{array}$ & $\begin{array}{l}-0.001 \\
(-0.96)\end{array}$ & $\begin{array}{l}-0.001 \\
(-0.96)\end{array}$ & $\begin{array}{l}-0.007 \\
(-0.86)\end{array}$ & $\begin{array}{l}-0.010 \\
(-1.34)\end{array}$ & $\begin{array}{l}-0.010 \\
(-1.34)\end{array}$ \\
\hline ROIAA*RISK-COMMITTEE & $\begin{array}{l}0.017 \\
(0.89)\end{array}$ & $\begin{array}{l}0.024 \\
(1.27)\end{array}$ & $\begin{array}{l}0.024 \\
(1.27)\end{array}$ & $\begin{array}{c}0.491 * * * \\
(4.01)\end{array}$ & $\begin{array}{c}0.523 * * * \\
(4.35)\end{array}$ & $\begin{array}{c}0.523 * * * \\
(4.35)\end{array}$ \\
\hline ROIAA*RISK-OFFICER & $\begin{array}{l}0.025 \\
(1.51)\end{array}$ & $\begin{array}{l}0.025 \\
(1.55)\end{array}$ & $\begin{array}{l}0.025 \\
(1.55)\end{array}$ & $\begin{array}{c}-0.180 * * * \\
(-2.80)\end{array}$ & $\begin{array}{c}-0.175 * * * \\
(-2.77)\end{array}$ & $\begin{array}{c}-0.175^{* * * *} \\
(-2.77)\end{array}$ \\
\hline ROIAA*FEMALE & $\begin{array}{l}0.130 * \\
(1.90)\end{array}$ & $\begin{array}{l}0.133 * \\
(1.94)\end{array}$ & $\begin{array}{c}0.133^{*} \\
(1.94)\end{array}$ & $\begin{array}{l}-0.043 \\
(-0.10)\end{array}$ & $\begin{array}{c}-0.004 \\
(-0.010)\end{array}$ & $\begin{array}{l}-0.004 \\
(-0.010)\end{array}$ \\
\hline IFRS & $\begin{array}{c}0.016 * * * \\
(5.05)\end{array}$ & $\begin{array}{c}0.016 * * * \\
(5.31)\end{array}$ & $\begin{array}{c}0.016 * * * \\
(5.31)\end{array}$ & $\begin{array}{c}0.009 * * * \\
(2.93)\end{array}$ & $\begin{array}{c}0.009 * * * \\
(3.00)\end{array}$ & $\begin{array}{c}0.009 * * * \\
(3.00)\end{array}$ \\
\hline BIG4 & $\begin{array}{l}0.001 \\
(0.15)\end{array}$ & $\begin{array}{l}0.001 \\
(0.07)\end{array}$ & $\begin{array}{l}0.001 \\
(0.07)\end{array}$ & $\begin{array}{l}0.001 \\
(0.13)\end{array}$ & $\begin{array}{l}0.001 \\
(0.08)\end{array}$ & $\begin{array}{l}0.001 \\
(0.08)\end{array}$ \\
\hline LNTA & $\begin{array}{c}-0.001 * * * \\
(-3.53)\end{array}$ & $\begin{array}{c}-0.001 * * * \\
(-3.78)\end{array}$ & $\begin{array}{c}-0.001 * * * \\
(-3.78)\end{array}$ & $\begin{array}{c}0.002 * \\
(1.79)\end{array}$ & $\begin{array}{c}0.002 * * \\
(2.10)\end{array}$ & $\begin{array}{c}0.002 * * \\
(2.10)\end{array}$ \\
\hline LNGDP & $\begin{array}{l}0.001 \\
(1.03)\end{array}$ & $\begin{array}{l}0.001 \\
(0.85)\end{array}$ & $\begin{array}{l}0.001 \\
(0.85)\end{array}$ & $\begin{array}{l}-0.001 \\
(-0.23)\end{array}$ & $\begin{array}{l}-0.001 \\
(-0.17)\end{array}$ & $\begin{array}{l}-0.001 \\
(-0.17)\end{array}$ \\
\hline Z & $\begin{array}{l}0.001 \\
(0.59)\end{array}$ & $\begin{array}{l}0.001 \\
(0.39)\end{array}$ & $\begin{array}{l}0.001 \\
(0.39)\end{array}$ & $\begin{array}{l}0.004 \\
(1.00)\end{array}$ & $\begin{array}{c}0.008 * \\
(1.70)\end{array}$ & $\begin{array}{c}0.007 * \\
(1.70)\end{array}$ \\
\hline TIER1 & $\begin{array}{c}0.033 * * \\
(2.57)\end{array}$ & $\begin{array}{c}0.034 * * * \\
(2.72)\end{array}$ & $\begin{array}{c}0.034 * * * \\
(2.72)\end{array}$ & $\begin{array}{c}0.082 * * * \\
(4.37)\end{array}$ & $\begin{array}{c}0.076^{* * * *} \\
(4.00)\end{array}$ & $\begin{array}{c}0.076^{* * * *} \\
(4.00)\end{array}$ \\
\hline DINSUR & $\begin{array}{l}-0.001 \\
(-0.092)\end{array}$ & $\begin{array}{c}0.001 \\
(0.078)\end{array}$ & $\begin{array}{c}0.001 \\
(0.078)\end{array}$ & $\begin{array}{c}-0.015 * * * \\
(-3.04)\end{array}$ & $\begin{array}{c}-0.017 * * * \\
(-3.49)\end{array}$ & $\begin{array}{c}-0.017 * * * * \\
(-3.49)\end{array}$ \\
\hline BHC DUMMY & & $\begin{array}{l}-0.001 \\
(-0.36)\end{array}$ & $\begin{array}{l}-0.001 \\
(-0.36)\end{array}$ & & $\begin{array}{c}0.007 * * \\
(2.17)\end{array}$ & $\begin{array}{c}0.007 * * \\
(2.17)\end{array}$ \\
\hline STD. ROIAA & & $\begin{array}{c}0.045^{* * * *} \\
(2.94)\end{array}$ & $\begin{array}{c}0.045 * * * \\
(2.94)\end{array}$ & & $\begin{array}{c}-0.170^{* *} \\
(-2.57)\end{array}$ & $\begin{array}{c}-0.170 * * \\
(-2.57)\end{array}$ \\
\hline CRISIS DUMMY & & & -0.00323 & & & -0.002 \\
\hline
\end{tabular}


Table 6 (continued)

\begin{tabular}{|c|c|c|c|c|c|c|}
\hline & \multicolumn{3}{|c|}{ Developed Countries } & \multicolumn{3}{|c|}{ Emerging Countries } \\
\hline & Panel A & & & Panel B & & \\
\hline \multirow{3}{*}{ Constant } & & & $(-1.233)$ & & & $(-0.12)$ \\
\hline & -0.002 & 0.005 & 0.005 & $-0.056^{* *}$ & $-0.061 * *$ & $-0.061 * *$ \\
\hline & $(-0.07)$ & $(0.14)$ & $(0.14)$ & $(-1.99)$ & $(-2.24)$ & $(-2.24)$ \\
\hline Observations & 472 & 472 & 472 & 263 & 263 & 263 \\
\hline R-squared & 0.24 & 0.26 & 0.26 & 0.76 & 0.77 & 0.77 \\
\hline
\end{tabular}

This Table reports the OLS regression results between earnings predictability, current earnings, and interactive corporate governance variables in the Developed and Emerging countries. The dependent variable is $\mathrm{CFO}_{\mathrm{t}+1}$. The variables descriptions are presented in Table 2. Panel A reports the effect of current earnings and interactive corporate governance variables on $\mathrm{CFO}_{\mathrm{t}+1}$ in Developed countries. Panel B reports the effect of current earnings and interactive corporate governance variables on $\mathrm{CFO}_{\mathrm{t}+1}$ in Emerging countries. Standard errors in parentheses. $* * * \mathrm{p}<0.01, * * \mathrm{p}<0.05, * \mathrm{p}<0.1$

Panel B the estimates for banks operating in emerging countries are reported and here our findings are similar to those in Table 3 for CEO power and risk governance interaction variables with current earnings, while not for board structure interaction variables. Clearly stages of economic development impact bank earnings quality.

We also re-estimate the same regression after splitting the sample according to bank asset size. ${ }^{9}$ The findings are somewhat mixed for large and medium-sized banks, although for smaller banks we do find stronger evidence that board structure and CEO power interaction variables help predict future bank earnings.

\subsubsection{Robustness checks}

To check the robustness of our findings, we estimate our baseline regressions using an alternative earnings predictability measure following Francis et al. (2004). This proxy is the standard deviation of the residuals $\left(v_{j}\right)$ defined from equation Earn $_{\mathrm{j}, \mathrm{t}}=\phi_{0, \mathrm{j}}+\phi_{1, \mathrm{j}}$ Earn $_{\mathrm{j}, \mathrm{t}-\mathrm{1}}+\mathrm{v}_{\mathrm{j}, \mathrm{t}}$ deflated by firm j's total assets, where Earn $\mathrm{j}_{\mathrm{j}, \mathrm{t}}=$ firms $\mathrm{j}$ 's net income before extraordinary items in year $t$, larger standard deviation of the residuals $\left(\mathrm{v}_{\mathrm{j}}\right)$ reflects lower earnings predictability. Our findings ${ }^{10}$ show a positive and significant relationship between current earnings and $\mathrm{CFO}_{\mathrm{t}+1}$ at the $10 \%$ level, consistent with the baseline findings in Table 3. Overall, board size has a negative relation, independent boards and interactive variable of earnings and independent boards a positive influence on future earnings predictability and supporting $\mathrm{H}_{1}$. Other findings also show that CEO power and interactive variables with earnings do not help predict future earnings (supporting $\mathrm{H}_{2}$.) and we do not find any support for an influence of risk governance factors and their interactive variables with earnings (no support for $\mathrm{H}_{3}$ ).

Finally, we re-estimate eq. 1 using the two-step system GMM approach ${ }^{11}$ adopted by Arellano and Bover (1995) and Blundell and Bond (1998) to help deal with potential

\footnotetext{
${ }^{9}$ Estimates are available from the authors on request.

${ }^{10}$ Estimates are available from the authors on request.

11 The GMM estimates are available from the authors on request.
} 
endogeneity/causality issues. Overall the main findings are in accordance with those reported in Table 3, namely, that board structure, CEO power and their interactive variables with earnings have a significant influence on the earnings predictability of banks, but this is not the case for the risk governance measures and their interactive variables with earnings.

\section{Conclusion}

We examine the impact of corporate governance on earnings predictability in all listed banks from 71 countries over the period of 2007-2016 in the light of IFRS/GAAP. High quality accounting numbers are important to banks (as well as other firms) because without accurate accounting information they are unable to precisely estimate their future earnings prospects and valuations. Under IFRS/GAAP frameworks we posit that higher quality reported bank earnings should be a better predictor of future earnings. Corporate governance mechanisms can also mitigate agency problems and enhance bank performance. Since operating earnings are a key contributor to bank performance, governance mechanisms should be in place to promote disclosure quality and ensure sustained earnings. Effective governance provides positive signals to the market regarding the capacity of the firm to generate sufficient earnings over time. Good governance should lead to quality disclosure and earnings and improved financial reporting that ultimately protect investors' interests and restrain managerial opportunism.

In particular, we evaluate whether current earnings, board structure and CEO power as well as the risk governance features of banks can effectively predict future cash flows $\left(\mathrm{CFO}_{\mathrm{t}+1}\right)$. Our results consistently suggest that $\mathrm{CFO}_{\mathrm{t}+1}$ is positively associated with current earnings. Interactive governance variables relating to board structure and current earnings generally show high explanatory power in influencing future CFO, as expected. However, such explanatory power tends to lessen in common law and emerging countries. Again, we find interactive $\mathrm{CEO}$ power variables reduce the predictability of future bank cash flows $\left(\mathrm{CFO}_{\mathrm{t}+1}\right)$. However, the negative effects of CEO power variables are more noticeable in common law and emerging countries. We also find that risk governance variables have little impact on earnings predictability. Further differences are observed for the influence of governance variables on different sized banks. Overall, these results suggest that the IFRS/GAAP disclosure regime and powerful board structure can contribute to determine future bank cash flows. These findings are robust to different sub-samples covering country legal status (common law/civil law), stages of economic development (developed/emerging) and different bank sizes.

Our results imply the importance of the accounting regime - IFRS/GAAP - and more specifically quality earnings as instrumental in reflecting future bank cash flows. The effects of standard governance interactive measures on earnings predictability, in particular small and independent boards enhance earnings predictability while CEO power tends to lessen predictability. Risk governance interactive features appear to have at best a marginal influence. The study highlights how board structure and risk governance features can influence earnings quality and highlights differences that occur depending on whether banks operate in various legal regimes (civil versus common law), and varying stages of economic development (developed versus. emerging) and for different bank sizes. Policymakers should perhaps consider strengthening the risk governance features of banks as these appear to have a limited influence on bank earnings quality. 
Acknowledgements We would like to express our appreciation to the editor, the special issue guest editors and an anonymous reviewer for their constructive comments. We acknowledge the financial support from Jan Wallanders och Tom Hedelius Stfitelse, Handelsbanken, Sweden (Project ID- P2011-0212:1), for this research. We thank Valentina Salotti for her valuable comments at INFINITI conference 2015 at Ljubljana, Slovenia. We are also thankful to Iftekhar Hasan and other participants at Portsmouth-Fordham conference 2016, and WHSS participants at the Stockholm Business School for valuable comments. We are grateful to Omar Sikder, Shakwat Hossain, and Sharifur Rahman and other research assistants for data collection. The authors are responsible for any remaining errors.

OpenAccessThis article is distributed under the terms of the Creative Commons Attribution 4.0 International License (http://creativecommons.org/licenses/by/4.0/), which permits unrestricted use, distribution, and reproduction in any medium, provided you give appropriate credit to the original author(s) and the source, provide a link to the Creative Commons license, and indicate if changes were made.

Publisher's Note Springer Nature remains neutral with regard to jurisdictional claims in published maps and institutional affiliations.

\section{References}

Adams RB, Almeida H, Ferreira D (2005) Powerful CEOs and their impact on corporate performance. Rev Financ Stud 18:1403-1432

Aebi V, Sabato G, Schmid M (2012) Risk management, corporate governance, and bank performance in the financial crisis. J Bank Financ 36:3213-3226

Agrawal A, Chadha S (2005) Corporate governance and accounting scandals. J Law Econ 48:317-406

Ahmed AS, Takeda C, Thomas S (1999) Bank loan loss provisions: a reexamination of capital management, earnings management and signaling effects. J Account Econ 28:1-25

Al-Dhamari RA, Ismail KNIK (2013) Governance structure and ownership structure and earnings predictability: Malaysian evidence. Asian Academy of Management Journal of Accounting and Finance 9:1-23

Altamuro J, Beatty A (2010) How does internal control regulation affect financial reporting? J Account Econ 49:58-74

Anderson KL, Gillan S, Deli DN (2003) Boards of directors, audit committees, and the information content of earnings (Weinberg Center for Corporate Governance Working Paper no. 2003-04). Retrieved from http://ssrn.com/abstract=444241. Accessed 23 Sept 2016

Arellano M, Bond S (1991) Some tests of specification for panel data: Monte Carlo evidence and an application to employment equations. Rev Econ Stud 58:277-297

Arellano M, Bover O (1995) Another look at the instrumental variable estimation of error-components models. J Econ 68:29-51

Arellano, M., Honoré, B., 2001. Chapter 53 - panel data models: some recent developments. In J. H. James \& L. Edward (Eds.), Handb Econ 5, 3229-3296

Atwood T, Drake MS, Myers LA (2010) Book-tax conformity, earnings persistence and the association between earnings and future cash flows. J Account Econ 50:111-125

Atwood TJ, Drake MS, Myers JN, Myers LA (2011) Do earnings reported under IFRS tell us more about future earnings and cash flows? J Account Public Policy 30:103-121

Bamber LS, Jiang J, Wang IY (2010) What's my style? The influence of top managers on voluntary corporate financial disclosure. Account Rev 85(4):1131-1162. https://doi.org/10.2308/accr.2010.85.4.1131

Bathala T, Rao RP (1995) The determinants of board composition: an agency theory perspective. Manag Decis Econ 16:59-69

Barth ME, Landsman WR, Lang MH (2008) International accounting standards and accounting quality. J Account Res 46:467-498

Beatty A, Chamberlain SL, Magliolo J (1995) Managing financial reports of commercial banks: the influence of taxes, regulatory capital, and earnings. J Account Res 33:231-261

Beltratti A, Stulz RM (2012) The credit crisis around the globe: why did some banks perform better? J Financ Econ 105(1):1-17

Berger A, Kick T, Schaeck K (2014) Executive board composition and bank risk taking. J Corp Finan 28:48-65

Blundell R, Bond S (1998) Initial conditions and moment restrictions in dynamic panel data models. J Econ 87: 115-143 
Brancato C, Tonello M, Hexter E, Newman KR (2006) The role of US corporate boards in enterprise risk management, the conference board research report no. R-1390-06-RR

Bushman R, Williams C (2012) Accounting discretion, loan loss provisioning, and discipline of banks' risktaking. J Account Econ 54:1-18

Cheng E, Courtenay S (2006) Board composition, regulatory regime and voluntary disclosure. Int J Account 41: 262-289

Chen CJP, Jaggi B (2000) Association between independent non-executive directors, family control and financial disclosures in Hong Kong. J Account Public Policy 19:285-310

Cho S, Rui OM (2009) Exploring the effects of China's two-tier board system and ownership structure on firm performance and earnings informativeness. Asian-Pacific Journal of Accounting and Economics 16:95-118

Cohen J, Krishnamoorthy G, Wright A (2004) The corporate governance mosaic and financial reporting quality. J Account Lit 23:87-152

Coles J, Daniel N, Naveen L (2008) Boards: does one size fit all? J Financ Econ 87:329-356

Collins JH, Shackelford DA, Wahlen JM (1995) Bank differences in the coordination of regulatory capital, earnings, and taxes. J Account Res 33:263-291

Cormier D, Martinez I (2006) The association between management earnings forecasts, earnings management, and stock market valuation: evidence from French IPOs. Int J Account 41:209-236

Cornett MM, McNutt JJ, Tehranian H (2009) Corporate governance and earnings management at large U.S. bank holding companies. J Corp Finan 15:412-430

Dalton D, Daily C, Ellstrand A, Johnson J (1998) Meta-analytic reviews of board composition, leadership structure, and financial performance. Strateg Manag J 19:269-290

Dalton D, Daily C, Johnson J, Ellstrand A (1999) Number of directors and financial performance: a metaanalysis. Acad Manag J 42:674-686

Dechow PM (1994) Accounting earnings and cash flows as measures of firm performance: the role of accounting accruals. J Account Econ 18:3-42

Dechow PM, Sloan RG, Sweeney AP (1996) Causes and consequences of earnings manipulation: an analysis of firms subject to enforcement actions by the SEC. Contemp Account Res 13:1-36

Dechow PM, Kothari SP, Watts LR (1998) The relation between earnings and cash flows. J Account Econ 25:133-168

Dechow PM, Skinner D (2000) Earnings management: reconciling the views of accounting academics, practitioners, and regulators. Account Horiz 14:235-250

Dechow P, Dichev I (2002) The quality of accruals and earnings: the role of accrual estimation errors. Account Rev 77(Supplement):35-59

Dechow, P.M., Schrand, C., 2004. Earnings quality. The Research Foundation of CFA Institute, No. 3

Dechow PM, Ge W, Schrand C (2010) Understanding earnings quality: A review of the proxies, their determinants and their consequences. J Account Econ 50:344-401

Dechow PM, Hutton A, Kim JH, Sloan R (2012) Detecting earnings management: a new approach. J Account Res 50:275-334

Dichev ID, Graham JR, Harvey CR, Rajgopal S (2013) Earnings quality: evidence from the field. J Account Econ 56:1-33

Dimitropoulos PE, Asteriou D (2010) The effect of board composition on the informativeness and quality of annual earnings: empirical evidence from Greece. Res Int Bus Financ 24:190-205

Doyle J, Lundholm R, Soliman M (2003) The predictive value of expenses excluded from pro forma earnings. Rev Acc Stud 8:145-174

Du Plessis, J. McConvill J, Bagaric, M (2015) Principles of contemporary corporate governance. Cambridge University Press, Cambridge, UK

Engel E (2005) Discussion of does the market value financial expertise on audit committees of boards of directors? J Account Res 43:195-204

Ellus A, Yerramilli V (2013) Stronger risk controls, lower risk: evidence from U.S. Bank holding companies. J Financ 48:1757-1803

Erkens DH, Hung M, Matos P (2012) Corporate governance in the 2007-2008 financial crisis: evidence from financial institutions worldwide. J Corp Finan 18(2):389-411

Firth M, Fung PMY, Rui OM (2007) Ownership, two-tier board structure, and the informativeness of earningsevidence from China. J Account Public Policy 26:463-496

Fracassi C, Tate G (2012) External networking and internal firm governance. J Financ 47:153-194

Francis J, LaFond R, Olsson PM, Schipper K (2004) Costs of equity and Earnings attributes. Account Rev 79: 967-1010

Greenberg RR, Johnson GL, Ramesh K (1986) Earnings versus cash flow as a predictor of future cash flow measures. J Acc Audit Financ 1:266-277

Gul, F. A., Lai, K. W., 2002. Insider entrenchment, board leadership structure and informativeness of earnings (Working paper no. 26/2002). Retrieved form http//ssrn.com/abstract= 304399 
Hair J, Black W, Babin B, Anderson R, Tatham R (2006) Multivariate data analysis. Pearson International Edition, Upper Saddle River, USA

Hasan I, Park JC, Wu Q (2012) The impact of earnings predictability on bank loan contracting. J Bus Financ Acc 39:1068-1101

Hashim HA, Devi SS (2007) Corporate governance, ownership structure and earnings quality: Malaysian evidence. Research in Accounting and Emerging Economies 8:97-123

Healy P, Wahlen J (1999) A review of the earnings management literature and its implications for standard setting. Account Horiz 13:365-384

Hermalin BE, Weisbach MS (1998) Endogenously chosen boards of directors and their monitoring of the CEO. Am Econ Rev 88:96-118

Holm C, Schøler F (2010) Reduction of asymmetric information through corporate governance mechanism - the importance of ownership dispersion and exposure toward the international capital market. Corporate Governance: An International Review 18:32-47

Hope OK, Thomas WB (2008) Managerial empire building and firm disclosure. J Account Res 46:591-626

Jensen MC (1986) Agency cost of free cash flow, corporate finance, and takeovers. Am Econ Rev 76:323-329

Jo K, Kim Y (2007) Disclosure frequency and earnings management. J Financ Econ 84:561-590

John K, Senbet L (1998) Corporate governance and board effectiveness. J Bank Financ 22:371-403

Kanagaretnam K, Lobo GJ, Yang D (2004) Joint tests of signaling and income smoothing through bank loan loss provisions. Contemp Account Res 21:843-884

Kanagaretnam K, Lim CY, Lobo GJ (2010) Auditor reputation and earnings management: international evidence from the banking industry. J Bank Financ 34:2318-2327

Kanagaretnam K, Lim CY, Lobo GJ (2014) Effects of international institutional factors on earnings quality of banks. J Bank Financ 39:87-106

Kashyap AK, Raghuram GR, Jeremy CS (2008) Rethinking capital regulation, Federal Reserve Bank of Kansas City Symposium on "Maintaining Stability in a Changing Financial System", Jackson Hole, Wyoming. Available at http://www.kc.frb.org/publicat/sympos/2008/KashyapRajanStein.08.08.08. pdf. Accessed 26 Feb 2016

Kent P, Routledge J, Stewart J (2010) Innate and discretionary accruals quality and corporate governance. Account Finance 50:171-195

Klein A (2002) Audit committee, board of director characteristics, and earnings management. J Account Econ 33:375-401

Kothari SP, Leone A, Wasley C (2005) Performance matched discretionary accrual measures. J Account Econ 39: 163-197

Leventis S, Dimitropoulos PE, Anandarajan A (2011) Loan loss provisions, earnings management and capital management under IFRS: the case of EU commercial banks. J Financ Serv Res 40:103-122

Levine R (2004) The corporate governance of the banks: A concise discussion of concepts and evidence. Working Paper, World Bank Policy Research

Linck J, Netter J, Yang T (2008) The determinants of board structure. J Financ Econ 87:308-328

Lipe R (1990) The relation between stock return and accounting earnings given alternative information. Account Rev 65:49-71

Mak YT, Li Y (2001) Determinants of corporate ownership and board structure: evidence from Singapore. J Corp Finan 7:236-256

Man C, Wong B (2013) Corproate governance and earnings management : A survey of literature. The Journal of Applied Business Research 29:391-418

Mashayekhi B, Bazaz M (2010) The effects of corporate governance on earnings quality: evidence from Iran. Asian Journal of Business and Accounting 3:71-100

May DO (1995) Do managerial motives influence firm risk reduction strategies? J Financ 50:1291-1308

Melumad ND, Nissim D (2009) Line-item analysis of earnings quality. Foundations and Trends in Accounting 3 : $87-221$

Mollah S, Zaman M (2015) Shari'ah Supervision. Corporate Governance and Performance: Conventional vs Islamic Banks Journal of Banking and Finance 58:418-435

Mongiardino A, Plath C (2010) Risk governance at large banks: have any lessons been learned? Journal of Risk Management in Financial Institutions 3:116-123

Morck R, Schliefer A, Vishny R (1989) Alternative mechanisms for corporate control. Am Econ Rev 79:842852

Nichols DC, Wahlen JM, Wieland MM (2009) Publicly traded versus privately held: implications for conditional conservatism in bank accounting. Rev Acc Stud 14(1):88-122

Organisation for Economic Co-operation and Development (OECD) (2010) Corporate governance and the financial crisis: conclusions and emerging good practices to enhance implementation of the principles. OECD, Paris 
Palvia A, Vähämaa E, Vähämaa S (2014) Are female CEOs and chairwomen more conservative and risk averse? Evidence from the banking industry during the financial crisis. Journal of Business Ethics, forthcoming. https://doi.org/10.2139/ssrn.2136978

Pathan S (2009) Strong boards, CEO power and bank risk-taking. J Bank Financ 33:1340-1350

Pathan S, Faff R (2013) Does board structure in banks really affect their performance? J Bank Financ 37:15731589

Pérez D, Salas-Fumás V, Saurina J (2008) Earnings and capital management in alternative loan loss provision regulatory regimes. Eur Account Rev 17:423-445

Prencipe A, Bar-Yosef S (2011) Corporate governance and earnings management in family-controlled companies. J Acc Audit Financ 26:199-227

Prior D, Tortosa-Ausina E, Illueca M, García-Alcober MP (2014) Earnings quality and performance in the banking industry: A profit frontier approach, Working Papers series no. 2014/11. Economics Department, Universitat Jaume I, Castellón

Rahman RA, Ali FHM (2006) Board, audit committee, culture and earnings management: Malaysian evidence. Manag Audit J 21:783-804

Rosenfield P (2000) What drives earnings management? J Account 190:106-109

Sabato G (2010) Financial crisis: where did risk management fail? International Review of Applied Financial Issues and Economics 2:12-18

Saleh NM, Iskandar TM, Rahmat MM (2005) Earnings management and board characteristics: evidence from Malaysia. Jurnal Pengurusan 24:77-103

Saunders A, Cornett MM (2006) Financial institutions management: A risk management approach. McGraw-Hill Companies Inc., New York

Schiemann F, Guenther T (2013) Earnings predictability, value relevance, and employee expenses. Int J Account 48:149-172

Schipper K, Vincent L (2003) Earnings quality. Account Horiz 17:97-110

Shen CH, Chih HL (2007) Earnings management and corporate governance in Asia's emerging markets. Corporate Governance: An International Review 15:999-1021

Shleifer A, Vishny RW (1997) A survey of corporate governance. J Financ 52:737-783

Srinidhi B, Gul FA, Tsui J (2011) Female directors and earnings quality. Contemp Account Res 28:1610-1644

Stulz RM (2008) Risk management failures: what are they and when do they happen? Journal of Applied Corporate Finance 20:58-67

Sundén A, Surette BJ (1998) Gender differences in the allocation of assets in retirement savings plans. Am Econ Rev Pap Proc 88:207-211

Sun J, Liu G, Lan G (2010) Does female directorship on independent audit committees constrain earnings management? J Bus Ethics 99:369-382

Vafeas N (2000) Board structure and the informativeness of earnings. J Account Public Policy 19:139-160

Velury U, Jenkins DS (2006) Institutional ownership and the quality of earnings. J Bus Res 59:1043-1051

Van der Meulen S, Gaeremynck A, Willekens M (2007) Attribute differences between US GAAPand IFRS earnings: an exploratory study. Int J Account 42:123-142

Xie B, Davidson W, DaDalt P (2003) Earnings management and corporate governance: the roles of the board and the audit committee. J Corp Finan 9:295-317

Ye K, Zhang R, Rezaee Z (2010) Does top executive gender diversity affect earnings quality? A large sample analysis of Chinese listed firms. Advances in Accounting, Incorporating Advances in International Accounting 26:47-54

Zhang Y, Wiersema MF (2009) Stock market reaction to CEO certification: the signaling role of CEO background. Strateg Manag J 30:693-710 